
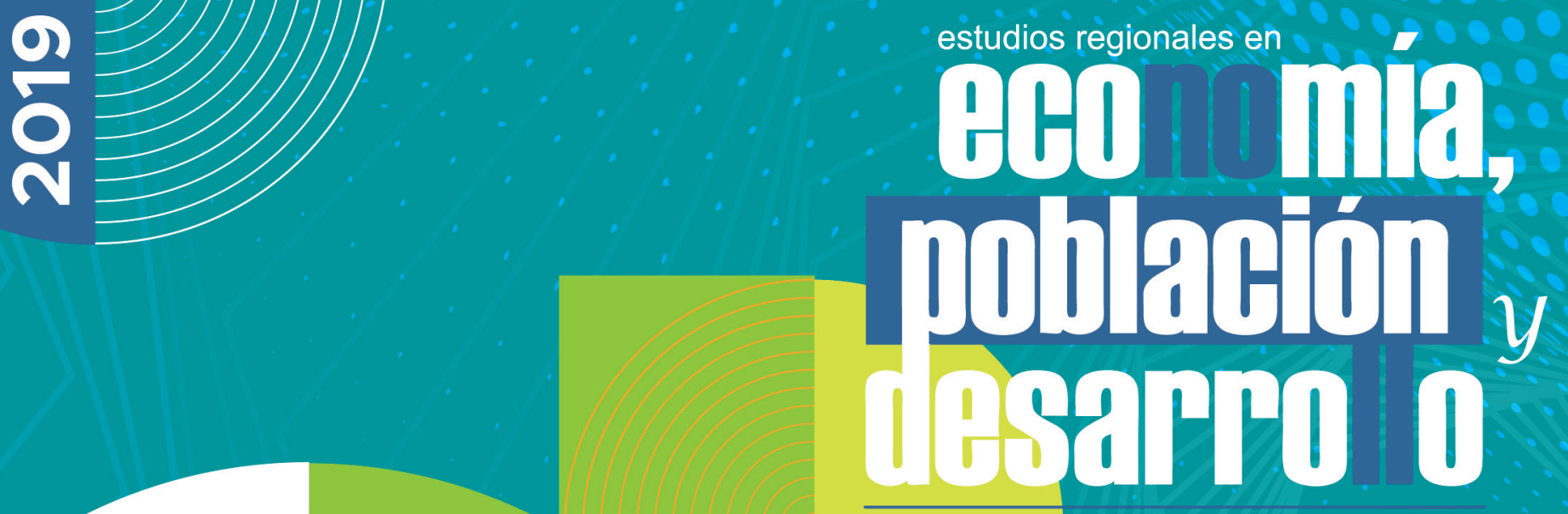

cuadernos de trabajo de la UACJ

How economics

forgot power

Carlos Mallorquin

UNIVERSIDAD AUTÓNOMA DE CIUDAD JUÁREZ

PUBLICACIÓN AFILIADA A LA

RED IBEROAMERICANA DE ESTUDIOS DEL DESARROLLO 


\title{
How economics forgot power
}

\author{
Carlos Mallorquin
}

\section{UNIVERSIDAD AUTÓNOMA DE CIUDAD JUÁREZ}

PUBLICACIÓN AFILIADA A LA

RED IBEROAMERICANA DE ESTUDIOS DEL DESARROLLO 


\title{
UNIVERSIDAD AUTÓNOMA DE CIUDAD JUÁREZ
}

\author{
PUBLICACIÓN AFILIADA A LA \\ RED IBEROAMERICANA DE ESTUDIOS DEL DESARROLLO
}

Universidad Autónoma de Ciudad Juárez

2018-2024

Mtro. Juan Ignacio Camargo Nassar

Rector

Mtro. Daniel Alberto Constandse Cortez

Secretario General

Mtro. Jesús Meza Vega

Director General de Comunicación Universitaria

Dra. Beatriz Araceli Díaz Torres

Coordinadora General de Investigación y Posgrado

Comité de Coordinación de la Red Iberoamericana de Estudios del Desarrollo 2018-2020

Dra. Paulina Sanhueza Martínez (Universidad de la Frontera, Chile)

Coordinadora General

Dr. Ignacio Rodríguez Rodríguez (Universidad de la Frontera, Chile)

Secretario general

Dra. Myrna Limas Hernández

(Universidad Autónoma de Ciudad Juárez, México)

Vocal de Organización

Dr. Pablo Galaso Reca (Universidad de la República, Uruguay)

Vocal de Organización

Dr. Luis Enrique Gutiérrez Casas

Director y editor de Cuadernos de Trabajo

Estudios Regionales en Economía, Población y Desarrollo

Comité editorial

Sección internacional Dra. Sofía Boza Martínez

(Universidad de Chile, Chile)

Dra. Olga Biosca Artiñano

(Glasgow Caledonian University, Reino Unido)

Dra. Ángeles Sánchez Díez

(Universidad Autónoma de Madrid, España)

Dr. Thomas Fullerton Mankin

(University of Texas at E1 Paso, Estados Unidos)

Dr. Adrián Rodríguez Miranda

(Universidad de la República, Uruguay)

Dra. Ikuho Kochi

(Kanazawa University, Japón)

Sección local

(Universidad Autónoma de Ciudad Juárez)

Dra. Myrna Limas Hernández

Dra. Rosa María García Almada

Dr. Raúl Alberto Ponce Rodríguez

Dr. Isaac Leobardo Sánchez Juárez

Dr. Héctor Alonso Barajas Bustillos

Dr. Juan Carlos Medina Guirado

Diseño de cubierta Abigail Bautista
Estudios Regionales en Economía, Población

y Desarrollo. Cuadernos de Trabajo de la UACJ

ISSN 2007-3739

Número 53. Septiembre - Octubre 2019

How economics forgot power

Carlos Mallorquin

Universidad Autónoma de Ciudad Juárez

Estudios Regionales en Economía, Población y Desarrollo.

Cuadernos de Trabajo de la UACJ

Año 9, No. 53 septiembre - octubre 2019, es una publicación bimestral editada por la Universidad Autónoma de Ciudad Juárez a través del Cuerpo Académico de Estudios Regionales en Economía, Población y Desarrollo. Redacción: Avenida Universidad y H. Colegio Militar, Zona Chamizal s/n., C.P. 32300, Ciudad Juárez, Chihuahua, México.

Teléfonos: (656) 688-38-00, ext. 3792. Correo electrónico: igtz@uacj.mx. Editor responsable: Luis Enrique Gutiérrez Casas. Reserva de derechos al uso exclusivo: edición impresa, ISSN 2007-3739., edición digital, No. de reserva 04-2019-050218151500. Impresa por Studio Los Dorados, calle Del Campanario, número 820-2, Santa Cecilia, C.P. 32350, Cd. Juárez, Chihuahua. Distribuidor: Subdirección de Gestión de Proyecto y Marketing Editorial. Ave. Plutarco Elías Calles 1210, Foviste Chamizal, C.P. 32310, Ciudad Juárez, Chihuahua. Este número se terminó de imprimir el 15 de agosto 2019 con un tiraje de 120 ejempares.

Los ensayos publicitarios son responsabilidad exclusiva de sus autores.

Se autoriza la reproducción total o parcial bajo condición de citar la fuente.

Registrada en: EBSCO RePEC

Publicación afiliada a la Red Iberoamericana de Estudios del Desarrollo

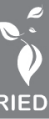

Universidad Autónoma de Ciudad Juárez

Ave Plutarco Elías Calles 1210

Foviste Chamizal, C.P. 32310

Ciudad Juárez, Chihuahua, México

www.uacj.mx

(C) Universidad Autónoma de Ciudad Juárez 
Estudios Regionales en Economía, Población y Desarrollo. Cuadernos de Trabajo, Universidad Autónoma de Ciudad Juárez, publicación afiliada a la Red Iberoamericana de Estudios del Desarrollo, número 53, septiembre - octubre de 2019, ISSN 2007-3739, pp. 3-33, México.

\title{
How economics forgot power
}

\author{
Carlos Mallorquin*
}

\begin{abstract}
Resumen
El artículo discute una reciente publicación de un libro de Philip Pilkington, en el cual se propone de manera innovadora una conceptualización del proceso de inversión (acumulación) y crecimiento económico. La mirada crítica a partir de la cual se examina el libro subraya ciertas similitudes teóricas que podemos encontrar en el discurso económico en América latina durante la década de 1950, generalmente denominada en el medio académico anglosajón o europeo como "estructuralismo latinoamericano", cuya perspectiva central es el examen de las formaciones económicas, así como sus agentes, productos de la configuración de las asimetrías de poder.
\end{abstract}

Palabras clave: Desarrollo, crecimeinto económico, asimetrías.

\begin{abstract}
The article discusses a recent book publication by Philip Pilkington, in which an interesting and novel reconceptualizing of the investment (accumulation) process and economic growth is proposed. The gaze and critique through which the book is examined underlines certain theoretical similarities found in the Latin American economic discourse during the 1950's, denominated as "Latin American structuralism", in Anglo Saxon or European academia. Central to its perspective is the examination of economic formations and its agents as a configuration of power asymmetries.
\end{abstract}

Keywords: Development, desarrollo, growth, crecimiento, asymmetries.

JEL Classification: B22, B41, B50.

- Recibido en: Enero de 2019.

- Aprobado en: Abril 2019.

* Profesor del Centro de Estudios para el Desarrollo de la Universidad Autónoma de Zacatecas.

Correo electrónico: carlosmallorquin1@gmail.com. 


\begin{abstract}
"That much economic theory is based on ridiculously narrow assumptions and unrealistic a priori premises should, at this stage, be obvious. But it is worth being clear how the types of people that espouse this sort of thing can be used by political forces that they do not understand and cannot comprehend. I have always been averse to the idea that economics as it is currently taught is some sort of organic outgrowth of the ideology of the ruling class. I do not find the Marxist story convincing that economics as it is currently taught is a mere reflection of the interest of the ruling class. Rather, I think that the explanation is much simpler: economists have cast such darkness over their own discipline that they can make themselves believe in basically anything that suits them at any given moment of time. All one has to do is feed them a very simple argument that seems internally consistent, and they will mistake this consistency for some Absolute Truth about the real world. Such people are very useful to the power-that-be. (...). Contemporary mainstream economics is less the ideology of the ruling class than it is the opiate for the establishment intellectuals who find that their little models and their ridiculously simplistic arguments get them invited to all the right parties" (Pilkington, 2016: 332)
\end{abstract}

\title{
○ 1. Introducción.
}

The heading of what follows, takes its title paraphrasing a book by G. Hodgson (How Economics Forgot History) ${ }^{1}$ revealing the central aspects of my comments on a recent book written by P. Pilkington (The Reformation in Economics: A Deconstruction and Reconstruction of Economic Theory, Palgrave Macmillan, 2016). My critique has a "southern" tone vis a vis the "northern" theoretical vocabularies (Connell: 2007, Lander: 2000), irrespective of which, it is a book which should be cheered by academics in general. ${ }^{2}$ Interestingly, and unknowingly vindicates "economics" as reconstructed in Latin America from the 1940's onwards in its goal for an alternative, independent theoretical vocabulary from the Eurocentric "imports", centering its analysis on the role of power asymmetries. In terms of the conception of a "discursive formation" ("power-knowledge") a la Foucault (Foucault, 1972), the "war of interpretations" presumes a repudiation of the notion of the existence of a necessarily "superior" discourse.

Pilkington's theoretical "demolition" reminds us of the Latin American structuralism perspective. The author of this book is certainly very brave and daring to pronounce and publish, what many members of the economic profession think about the dismal state of their discipline, theoretically as well as codes of conduct, but of which are disinclined to express overtly. The image of the congeries in question, it's manners and shallow "natures" are reminiscent of a Luis Buñuel movie, The Exterminating Angel, (no pun intended!) which in Buñuel terms, deals with a plot in which "a group of persons [inexplicably] cannot do what they wish to do: leave the room" (Buñuel, 1982: 232).

\footnotetext{
${ }^{1}$ (Hodgson, 2001; London/New York: Routledge).

${ }^{2}$ I thank equally Philip Pilkington and Colin Danby for their inputs; responsibility for what follows is absolutely mine.
} 
With profuse perseverance, given the unveiled discussions dedicated to the "profession" the narrative shows little leniency, bestowing very "harsh" (Pilkington, 2016: 353) words towards its incumbents. However, an absence in certain sections of the text related to an explicit concept which might help differentiate "ideological" from "nonideological" theoretical discourses replicated by these "well meaning" persons, gives the impression that they should be forgiven, for as the Christian saying goes: "they know not what they are doing". Neoclassical or marginalism, curse and cloak is presented as a misguided "ideology" chasing the "Holy Grail", with an erroneous role of mathematics in the "real sciences": "everyone remains trapped in his/her own personal political prison. But it is a happy incarceration" (Pilkington, 2016: 353).

A book of this nature it's a prologue, a "promise", which carries severe responsibilities. It might sound strange that a book dedicated to something called "economics" implicates a decision, an ethical command to act otherwise. The question is whether Pilkington is ready to fully embark on that path. If not, then the procedure of "deconstruction" undertaken it's just another irresponsible ploy of the kind he so thoroughly and correctly critiques in "mainstream" and/or "marginalism economic" profession. "Philosophizing with a hammer" (paraphrasing, Philip Mirowski), implies a critical decision to reconstructively pick up certain pieces given the fallen (?) edifice of mainstream economics. It is difficult, given my political perspective and Latin American prejudices not to share much of the criticism of "equilibrium economics" stated by Pilkington. It's the logical and political consequence of Raúl Prebisch, and Celso Furtado (among others) work, whose reconstruction of development discourse, during the 1950's and 1960's, "for and from the "south" assumed querying the discourses emanating in the "north".

Absence of space and objective of what follows, only touches in passing Pilkington's critique of the IS/LM and Krugman's interpretation of the "liquidity trap" concept, but once it is accepted that money is an "endogenous" creation, and not related necessarily with its supply and the "rate of interest", the LM-curve is always flat and the "liquidity trap theory" "loses one of the legs on which it stands" (Pilkington, 2016:181), ${ }^{3}$ and therefore level of economic activity does not automatically grow with "cheap money".

On the other hand, if Krugman's statement is sincere ("the theory of economic development was correct"(Krugman, 1997: 29) it follows that, economics recovers and supersedes in Hegelian fashion "Classical political economy" in both its "neoclassical" and "Marxist" offsprin$\mathrm{g}^{\prime} \mathrm{s}$, which implies the examination of the power asymmetries' constituting the social relations and agents in the "economic" realm.

${ }^{3}$ The model is "not innocent" (Pilkington, 2016: 181), it shapes the mind of those trained by it, and is "inherently conservative", in a sense it's an "updated version of the Quantity Theory of Money" but "harder to attack", because its underlying assumption of the "LM-curve" is that "money is scarce" which "if money is not created in line with some very rigid, mystical and usually arbitrary rule or set of rules, something awful will happen. Typically (...) hyperinflation" (Pilkington, 2016: 182). See also De Vroey, Hoover K.D, editors (2004). 
Having displaced the IS/LM "workhorse", Pilkington does the same with mainstream's theorization of the rational calculator, "maximizing" or "representative agent", which hinders comprehending "investment"/accumulation", growth and/or evolution of economies. Equally the agent in question should not be accorded the theoretical role in question since the economy as a whole cannot be reduced to the respective sums and actions of those "agents" in their capacity as individuals, and therefore "economics" should deal with "general categories" privileging macro abstractions related to "accountancy" rather than "sociology" or group psychology, those categories related with "income flows".

An approach to recover the importance of considering the productive and distributive aspects of those social categories, implies linking theoretically the latter in terms of the asymmetries' of power of which they are its effects: agents and their conditions of existence are the consequence of the antagonisms and power asymmetries, and these agents need not necessarily be "human individuals" (all sorts of corporations, "universities", "trade unions", "households", "states", etcetera), all of which have the pertinent recognition mechanisms through which to undertake choice-decisions. On the other hand, their antagonistic mode of constitution (the social relations), are always a contingent, transient characteristic, which forms part of the explanation to understand the heterogenous features of most agents. The power asymmetry generates the heterogenous characteristic of the agents: relates to the mode by which agents possess in separation certain of their conditions of existence of the agents or of the units of production, the "remainder" of which have to be, negotiated, bought, etcetera, especially with other "economic" agents strictly speaking. ${ }^{4}$ Therefore the antagonistic moment, always contingent, is constitutively associated with the "price" or "value" which they can enforce or assume, whether "capital" or "labour": Latin American structuralism claims that these categories have no general form of being or unity: on the one hand, these entities are not necessarily "human", but on the other, most important also they possess in separation, with respect other agents, no more than specific aspects of their conditions of existence. The heterogeneous quality of the agents presupposes no "general conditions", given the contingent-antagonistic power asymmetries' of power within and between agents. Therefore "price demand and supply elasticities", as well as "comparative advantage specialization" are theoretical concoctions of marginalism, which hide the historical construction and the power asymmetries involved as well as their potential transformations.

Both, within and between specific economic formations, as "center-periphery" entities for example, as Prebisch purport, refer to notions which are not necessarily a geographical "developed - developing" couple, since the "periphery" also exhibits a mixture of "center-periphery" antagonisms and power asymmetries. The heterogenous constitutive aspects within and without

${ }^{4}$ Pilkington's use of "kaleidoscopic" -see further ahead- or the "non-ergodic" (Pilkington, 2016: 55) logic of the realm in question requires, assuming these notions. 
of the "economies", "center" and "periphery", alike, are the product of those power asymmetries' mentioned before, and which, can be reinforced with Pilkington's Kaleckian vocabulary.

What ensues intends to portray the interesting aspects of his proposal, as well as the ambiguous nature of certain facets of his work to revert economics to theorize power, ${ }^{5}$ by incorporating Latin American structuralism and Kaleckian vocabulary; the text is subdivided by various sections, "Businessmen pay profits to each other" we devote much space to the reconstruction of the investment-profit elaborated by the author; followed by a segment ("Ruling the Roost") which concentrates in certain aspects of the narrative on the "international trade" logic among differing economic formations, and finally, in the last part "You want the social?" we insist on importance of engaging "politically" or "ethically" in economics, which paraphrasing Marx, then becomes much more a strategy to transform the world, rather than interpreting it.

The persistence and dominant characteristics of the institutions which generate the diffusion of mainstream economics or "marginalism", those "social and ideological" practices which require without a doubt a discussion and explanation, and of which there is plenty in Pilkington's book will be left aside for another occasion. What we wish to underline is the generally explicit theoretical insistence that agents and "markets", are constitutively "antagonistic" given the power asymmetries and although this nomenclature might be distasteful to Pilkington, it is necessary to stress this aspect since on certain occasions, the ambivalent quality of his "deconstruction-reconstruction" initiative could be associated with dodging the ethical political consequences involved.

\section{2. "Businessmen pay profits to each other".}

The expression with which we initiate this section, using Prebisch's words (Prebisch, 1948a: 336, 337, 338; 1949a: 417, represents one of the mechanisms by which profits and the macroeconomic investment carrousel process can be explained, or equivalently, Kalecki's singular turn of phrase "when workers spend what they earn capitalists earn what they spend" (Kalecki in Lopez, Assous, 2010: $31 ; 82 ; 215)$, points to the same outcome. Both focus their account in terms of power asymmetries among and between the agents. Although Pilkington's very interesting posing of the problem of "investment" and/or accumulation incorporates certain Kalecki's and Keynesian themes (specially the work of Shackle), Kalecki's explicit notion on "degree of monopoly" (Lopez;

\footnotetext{
${ }^{5}$ I use the term revert because "Political economy" lost those potentialities with the hegemonic role which Ricardian economics instilled during the 19th century; no space here to develop the idea that Marx unwittingly forms part of a discourse which also requires "deconstruction", and which in part the account here in process conveys. For example, Armando Di Filippo's theoretical recent description of the past is interesting in this line of thought (Di Filippo, 2013), as well as Osvaldo Sunkel (1970).
} 
Assous, 2010: 78;82;86;87) ${ }^{6}$, to understand the investment decision process, tends to recede in the background in Pilkington's account, aspects which will be discussed further on.

On the other hand, the undulatory or wave like movement, or "cyclical" image of "capitalism's" growth in the work of Prebisch, which can be represented by Minsky's remark: "Keynes put forth an investment theory of fluctuations in real demand and a financial theory of fluctuations in real investment" (Minsky,1975: 57 in Lopez; Assous, 2010: 243), is obligatory by the narrative in question and of which Pilkington is well aware. Growth and investment observe a "rise to either a stable path of low-inflation equilibrium growth' or "unstable path of high-inflation disequilibrium growth" (Pilkington, 2016: 198), but the story sometimes does not assimilate fully the antagonistic contingent existential element determined by power asymmetries, which in Pilkington's own words "ultimately determines the profit margin" (Pilkington, 2016:197).

Although aiming to formalize Keynes "marginal efficiency capital argument" (Pilkington, 2016: 251), he concedes that allusions to the question are not necessarily an "accurate depiction" of how "investors make investment decisions" (Pilkington, 2016: 251):

\begin{abstract}
"there is good reason to suspect that this is not altogether accurate depiction of how investors make investment decisions and needs to be modified. Shackle reports that when he interviewed businessmen, they did not think too much about the levels of interest rates when making investment decisions (Shackle 1966, pp.150-59) (...) Shackle found that businessmen typically make decisions based on whether a given piece of capital equipment can pay itself off (amortise) over a short period of time (...) based on their subjective evaluation or their animal spirits but these are cast over the short term because they believe that they are completely uncertain with regard the long run. It seems likely, that different people within a modern firm undertake investment decisions to the people who allocate internally generated funds and seek to borrow money. (...) it is likely that the people who make decisions about how much to invest are typically given a sort of menu of the funds available to them (...) they (...) weigh up potential profits against their potential losses and try to come to a decision about how much to invest. (...) the above framework is probably still a good starting point to understand the complexities of the investment decision-making process." (Pilkington, 2016: 251 my emphasis).
\end{abstract}

\footnotetext{
${ }^{6}$ Not to be confused with: "monopoly power" (Lopez, 2008: 52); furthermore as Lopez; Assous, insist "Kalecki rejected the view that macroeconomic results can be reached by simply adding up what is valid at the level of a particular firm" (Kalecki in Lopez; Assous, 2010: 74); "firms operate in imperfect markets, within which they possess a certain monopolistic power, due to the differentiation of their products. In this context, firms can fix their price by applying a certain margin to its unitary prime unit costs. The existence of this margin, whose level depend on the firms' monopolistic power, implies that the marginal productivity of labour will exceed the real wage per worker, so that there is no univocal association in existence (least of all a negative one) between employment and wages. As to the relation between the price and prime unit costs established at the aggregate scale, [Kalecki] calls 'degree of monopoly' (a concept which is distinct from 'monopoly power')" (Lopez, 2008: 52, my translation and emphasis).
} 
The emphasis above aims to characterize those heterogenous aspects of the internal organization of the agent, and the "participants" of the decision-choice response process, and likewise the agency itself with respect other potentially antagonistic agents: we therefore encounter a double contingent moment of the choice-decision process: internally the disparate sectoral management's division of labour and those engaged in the final decision-choice vis a vis the "external" contesting agents.

Hence the double heterogenous movement complex, a kaleidoscopic form of organization, as an outcome of the asymmetries of power, in a context in which their conditions of existence are themselves "heterogenous": they are not general, nor predetermined, given their intrinsically antagonistic and contingent character: "markets" are themselves composed of heterogenous motley of agents, whether in "financial" as well, as "productive" sectors, in other words, they do not conform a unity form of being.

Notwithstanding the above, firms (agents) and their pricing mechanisms or profit schedules have relatively few problems in calculation since these aspects, like "prices" are a convention or an "institution", which is sustained by a set of "habits" (Hodgson, 2004; 2006).

Prices do not represent "marginal revenues" at all, they are the consequence of simple summation of "direct material costs, labour costs and overhead costs determined at a 'standard' volume of output" (Pilkington, 2016: 196), after which, firms simply add a "percentage-based" 'mark-up' "that included both a profit element and also took into account any costs related to selling goods together with any interest payments the firm had to make" (Lee 1984, p. 152 in Pilkington 2016: 196). Also, and most importantly, Pilkington and Lavoie (2006), recognize, units of production rarely work at full capacity, hence their ability to increase production immediately if demand rises. In other words, the book excludes the typical section explaining the cost and supply-demand schedules as an outcome of the relative "demand-price elasticities" of the goods in question.

According to Pilkington, firms check each other's profit margin levels which in turn served to give the industry a sense of "stability" (Pilkington, 2016:196), avoiding undercutting each other, or price wars, nor aiming to raise too much their profit margins. The action, its logic, stabilize the horizon for the decisions-choice in an uncertain environment, conforming to certain patterns fitting common practice (Hodgson, 2004; 2006) notion of agency and routines guide example), the "mark-up theory of profit" explains why "profit do not simply disappear over time. Profit margins are conventions, and they exist in the form that they do so long as people believe that they should exist in this form." (Pilkington, 2016:197). The important principle of this long explanation, aims

\footnotetext{
${ }^{7}(1+\boldsymbol{\theta})$ AVG $=$ p; p prices, $\boldsymbol{\theta}$ percentage mark up, AVG, average costs. Now this formula can be broken up into money value (Pilkington, 2016: 196): $I+\mathrm{SAL}+\pi \equiv \boldsymbol{\Theta} ; \boldsymbol{\Theta}$ mark-up in money terms, $I$ payments on interest and SAL, cost incurred, transactions costs, and $\pi$ actual profit of the firm.
} 
to underline that profits are a "creature not so much of competition as they are of convention" (Pilkington, 2016:197), but Pilkington having grasped the image of the profit logic, strives to answer a further question which is not necessarily mandatory: why is the "customary norm" not broken? It hinges on something he mentions as "toleration" (Pilkington, 2016:197) wage and/or profit margins and/or higher prices, which can be reframed instead in terms of the respective asymmetric power relations among and within agents.

In an ambiguous fashion, the description above, tends to underplay, what is crucial to the whole explanation, which Pilkington calls "tension" or "class tension", again it seems that which can be called the antagonistic choice-decision moment is evaded: agents need not necessarily keep the same profit margins or level of wage/prices. It's an antagonistic contingent existential element determined by power asymmetries, which "ultimately determines the profit margin" (Ibid.,197) and it's this "tension" which gives "rise to either a stable path of low-inflation equilibrium growth" or "unstable path of high-inflation disequilibrium growth" (Ibid.,198). In marginalist economics, this attribute only belongs to specific "monopolistic" firms, assuming a certain "size" and the rule of economies of scale, otherwise it has no sovereign power to impose "mark-up" costs to establish certain "prices" and hence "profit margins", which must be said, it is contradicted by most of the literature which examines firms's costs and behavior projections. The "mark-up pricing" (Pilkington, 2016:198) responds to, as mentioned before, to that which Kalecki terms as the "degree of monopoly", ${ }^{8}$ or "asymmetric power relations" (in Latin American structuralism), notions which are not ubiquitous nor constant, given the heterogeneity characteristics of the agents in question and their conditions of existence. The potential profit "margin" within and among units of production, the unitary prices and wage-salary levels, are the consequence of these power asymmetries, on the other hand, in Prebisch and Kalecki's argument, there is no "unique and univocal (much less a negative one)" tendency "between employment and salaries" (Lopez, 2008: 52). In Prebisch's vision, the pricing procedure does not assume nor requires following a general rule, and salary levels, are related to the "unions action", (Prebisch: 1948b: 358) "workers pressure" (Prebisch: 1948a: 341; $344)^{9}$ whether at the micro or macroeconomic scale: during the "upswing" prices rise, at real wages expense, or other sectors, allowing henceforth for profits to materialize in the entrepreneurs hand, as well as incrementing the rate of savings, but it is during the downswing that the "fruits of technical progress" are transferred with less or greater extent depending on the antagonistic context of the community in question, aspect which has nothing to do with "competition": as prices rise faster

\footnotetext{
${ }^{8}$ Not to be confused with "monopoly power".

${ }^{9}$ Lopez; Assous: "income distribution is the result of the clash between the two opposite classes. To quote Kalecki's words used in the title of his last paper on the subject, the "Class Struggle [determines the] Distribution of National Income" (Kalecki 1971 [1991]). But the class struggle manifests itself both in the labour market and in the market for commodities in general. The degree of monopoly reflects the relative force of capitalists and workers in these two markets" (Kalecki in Lopez; Assous, 2010: 71; my emphasis).
} 
than nominal wages during the upswing, during the downswing of the cyclical movement the same forces in action are those which reduce the "prices", but since prices "don't decline with the same intensity" as wages, it is precisely during this moment of the cycle that the "fruits of technical progress are transferred" to the collectivity, (Prebisch, 1948b: 358). ${ }^{10}$ In other words, "wages" are lowered during the rising prices, but not to draw, as the classical doctrine would have it, a greater "saving" ratio from top income sectors through a raise in the interest rate, but rather so that "businessmen can accumulate compulsively the savings of the rest of the collectivity" (Prebisch, 1948b: 358).

Using Prebisch's expression: "businessmen pay each other profits", in the context of Pilkington's description of the growth process, implies the idea that higher unitary profits per product during the upswing, does not mean unescapably a lower "aggregate" level of total "profits" as a consequence of a price decrease per product during the downswing. Although the rate at which prices drop during the downswing is greater than the corresponding change of prices during the upswing, lower unitary profits per product requires considering the "distribution" antagonism between certain sectors, and/or between differing economic formations (Time disparity between those incomes leaving certain areas and the Time lapsed during its return - centre-periphery). Profits, in Prebisch's perspective, depends on two elements: the productive process and the monetary mass generated during the last and all preceding productive processes, therefore whatever antagonisms or "competition" for profit may have prevailed among entrepreneurs, it does not "alter its quantity

\footnotetext{
${ }^{10}$ Kalecki, despite his own efforts to establish a "rigorous and mathematical, business cycle model" (Lopez; Assous, 2010: 223), a general theory of an endogenous "cycle", finally conceded to the unlikelihood in question, which meant maintaining, a certain specific parameter to explain the cycle's ("endogenous") movement and simultaneously, accept that the contingent historical antagonistic logics of investment-choice decisions could not be generalized; Prebisch, although sharing Kalecki's idea of an inherent "desequilibrium", "wave like motions" of "capitalism" as its essence par excellence, presents no general theoretical effort to argue the "endogeneity" source of the historical movements which are represented in a graphical image, with no formalization or mathematical representation of the model. In Prebisch's perspective, graphical representation of the movements in question, (Prebisch, 1949a: 484, 419) assumes the inclusion of the notion of Time, which is introduced in the realm of the agents decision-choice horizon, transforming the very concept of "Time", "Time" itself paradoxically has an "asymmetric" character, whatever its units, its scale, metric or "clock-time", it cannot be made monotonic to a series sets of monetary units and investment and profit calculus. Literally, as the famous Shakespearian quote reads, for Prebisch, "time it's out of joint", refers not just to the issue of the asynchronous feature of the articulation between, the circulating and productive capital, "cycles" in space and "time", in which the respective "center-periphery" divide shows a constant reversal and "return" of income flows against the periphery; all of which implies that Times's "differ": Time's divergent logic is the consequence of differing antagonistic power asymmetries of the capitals, for Prebisch (in a certain sense Prebisch shares with his compatriot Borges notion of Time in question) "Time" itself could not be made sense of in "economic" or "price" terms. (Mallorquin, 2015) Hence the "disequilibrium" implies jettisoning notions of equilibrium, or "imperfect markets"; "competitive" or "monopoly". Kalecki, in contrast, with no detriment to his general perspective, as an aggregate demand effective theorist, on par or even prior to Keynes famous work of 1936, understood what it meant to construct the formalization of a general model of the business cycle: "what was logically required for constructing a mathematically robust endogenous explanation of fluctuations is that the stationary equilibrium must be unstable, so that the system will never reach it. Thus, abandoning the reference to random shocks, he developed a new explanation fundamentally endogenous in which fluctuations result mainly from waves of optimism and pessimism. In the second place, he enlarged the scope of his model, with the aim of formulating a dynamic system whose solution would encompass both the cycle and the long-run development of the capitalist economy.(Lopez; Assous: 2010: 92). Nonetheless, there is no space to discuss that perhaps the "Frisch-Kaldor-Kalecki", "endogeneity", "rocking chair" illustration, to theorize the causality in question might not be a "problem" at all; see Besomi, (2010); Louçã, (2001).
} 
or its variations", only the "distribution within the group of the businessmen" (Prebisch, 1948b: 355 , my emphasis). ${ }^{11}$

The pricing procedure forms part of a -contested- "ritual" or habits ingrained in the agents behavior repertoire, through which in turn they sail into antagonistic uncertain waters, domains where the "rational or representative agent" is off base: "prices are set by businesspeople long before the goods are even produced let alone brought to the market" (Lee 1984, pp.159-160 in Pilkington 2016, 198), denoting the materialization of the respective differing profits rates, an "irreversible process" (Prebisch, 1948a: 336). The indecisive-uncertain image, portrayed by Marx as the Salto mortal, is simply impertinent: the money which will "buy" or "clear" the market of its products, has been previously emerging during the ongoing or the earlier stages of the cycles of production, today's act of selling is the consequence of money-income whose sources were initiated in previous production processes (Prebisch, 1948b: 337). Performatively, profits are established the minute the entrepreneur does its bookkeeping. The so called "bargaining process" to establish "prices" and "costs" of goods, has taken placed "before" their appearance in the market, including the divergent profit margins and shares among and between the antagonistic heterogeneous unitsagents of production, related to the power asymmetries and antagonisms of the units in question (labor/firms; firms versus firms); an aspect associated in marginalist economics only within the "monopolist" span of agents. Given the heterogeneous nature of the agents, which is a consequence of the asymmetries of power, "marginalist" economics in Pilkington words, executes an "enormous violence to the real world" (Pilkington, 2016: 199).

But the critique of marginalism by Pilkington underlines an intromission which he sometimes typifies as "inherently totalitarian" mode of thought, given the varieties of "violence" which "data" and "agents" have to withstand given the "a priori" framework. It generates negative effects in the mode of thought of students, encouraging viewing the world in a twisted and "distorted way" (199). At issue once more, is the power asymmetries, which form the basis of the mechanism by which some information/ideas are incorporated when specific policies are promoted and

\footnotetext{
${ }^{11}$ No space to expand on Prebisch's theory on the appearance of "profits", suffice for now is to mention he has an "endogenous" notion of the creation of money (Prebisch, 1944) (Mallorquin, 2015) on which most of Pilkington's book is well versed. The idea of profits, combines the notion that a greater mass of money-income is presumed before the one but last productive process locates its goods in the "market", the corresponding money mass enables to "soak up" the "fruits of technical progress"; the sources of money income in question, is explained by the progression swelling of the monetary mass generated previously and by those productive investments projects in process: in a paradoxically manner, "today's product" and its corresponding profits, is "realized" by money incomes which was previously generated. These aspects of the materialization of profit and productive process are irreversible, subsequent productive cycles assume certain expected profit levels from past experience. This process stalls or begins to slow down, amongst other reasons, if entrepreneurs consider a too high level of inventory accumulation and which therefore induces a lower rate of future investments in accordance with what is considered pertinent.
} 
elaborated. And although Pilkington's critique might be turning on its head the sovereignty of the "marginalist" individualist perspective, his general view of "power", or its ambiguous references to "Kalecki", tends to obscure the specification of the asymmetries in question. For example, an alternative and more uniform arrangement of income distribution does require some form of "compulsion", direction, regulation, which we are not sure Pilkington is willing to defend.

Another of Pilkingston's quote of Joan Robinson (1953, 227), is instructive to highlight the ambiguous nature of the notion of power in his critique: "The search for the theory of a normal rate of profit is a bit like looking in a dark room for a black cat that probably is not there" (my emphasis C.M. )

If profit margins are "largely a political, cultural or social question" Pilkington, (2016: 199), more important, and interestingly is "where profits in the aggregate come from" (Pilkington, 2016: 199), and yet in the discussion of aggregate profits, Pilkington, uses the classic marginalist narrative ploy of the "island", a "silly parable" which he acknowledges in a foot note (Pilkington, 2016: 215), but which allegedly in his case, in contrast to marginalism, adopts more realistic "assumptions" (Pilkington, 2016: 215). In the last instance, the debate which balances a specific set of "realist" presuppositions vis a vis a different scheme has always been determined by a "conventionalist" discourse whose substratum changes easily with new trends. Therefore in marginalism, the Robinson Crusoe imaginary, as a ploy to evade the political examination and hence power asymmetries among and between agents, wishes to escape the notion of power, or in Wade Hands (2005) terms it does "not want the social" as we are to argue further ahead.

For the explanation on the appearance of aggregate profit, Pilkington recovers the imaginary narrative of the "silly island", which unlike its "marginalist" version, portrays some institutionally established rules like an obligatory minimum wage (a government), and a guaranteed stock of food to sustain the worker's while it labours its first working period; a bank which lends the money to the capitalists, to undertake the payments for the building of the factory and producing the food in question, which will be bought by the workers in question. At the end of the first period, there is no need to employ the same numbers of workers, since the factory has been completed. The capitalist has accrued to its bank account the aggregate expenditure of workers (his profit) minus the proportion which he pays on interest to the bank. The possibility of laying off some workers for the next production period means that aggregate expenditure or investment will be reduced and hence a potentially reduced level of aggregate profit, which ultimately could generate a "deflationary" situation since the workers will receive an excess of products above of what was their income. It's at this stage that Pilkington brings in "government" spending to underline that in a "closed economy with no net government spending profits are equal to investment" (Pilkington, 2016: 201). Pilkington's illustration brings to light the importance of government expenditure to sustain 
a certain level of investment. Government creates, through the central bank the extra cash "out of thin air" (Ibid., 201) (as explained by his critique of IS-LM workhorse, underlining the role of the central bank's target to set the rate of interest and not the total stock of money), ${ }^{12}$ the proportion of expenditure to sustain the level of investment previously reached, which means that the aggregate profits will return to its previous level. And profits will depend simultaneously by the "private sector" and government sector investments. Capitalists profit flow level will continue the same, and with each subsequent period of production, capitalists profit stock will grow systematically. Obviously if the capitalist decides to cancel it's debt with the bank, the latter's profit stock stops increasing. Up till now, prices have been stable, wages and investment "clears" the market of products, but with a rise of a salary by the government in favour of a specific sector of the work force (increasing expenditure), the proportional share which each group appropriates has shifted, within the class of labourers: the higher earning sector bids up the prices and the asymmetric distribution of the product initiates its course. Meanwhile the capitalist's profits has been amplified through the "inflationary" wage rise procedure, but soon other worker's sectors bid for a wage rise to recover its proportional share of the product lost by the original wage hike level. After an initial erosion of profit stock levels, given "inflationary" pulls, it subsequently recovers. Given that the banker ties his debt in nominal terms, not real terms, which is not based on the basket products it can buy, inflation swallows his interest payments away, while the capitalists debt in interest payments is lower in real terms as time ensues, henceforth "in an inflation real wealth will be redistributed from creditors to debtors" (Pilkington, 2016: 204). This focuses on the famous Kahn multiplier, ${ }^{12}$ a certain increment in expenditure, generates a further outflow of disbursement giving rise to a boost in the product output. It revolves around the notion of the marginal propensity to consume, which is relatively divergent between different sources of income, given specified consumption thresholds rates for the same set of goods on the part of certain agents.

The so called "Levy-Kalecki Equation" $\mathrm{Y} \equiv \pi+\mathrm{W},{ }^{14}$ is fetched to portray gross profits "economy as a whole" (Pilkington, 2016: 209) (GDP) in an economic formation, which in terms of investment

\footnotetext{
${ }^{12}$ Let's mention in passing that "creditor-debtor" entities declared are not necessarily "human individuals". The social relations which seems to determine interest rates, according to Pilkington, are related to the asymmetries' of "extractive power" (247). Having rejected the existence of "objective probabilities" which presume knowledge of future income and default prospects, Pilkington constructs a basic interest rate ratio: a debtor's income (y) or the "information" and debtor's "default rate" (dr) : i = dr/ y, and if future income (information) and probability of default are unknown, given the absence "objective probabilities", it could still be argued, from a more "pragmatic" view that what is at stake here is the waves of optimism and pessimism in the credit cycle. Fortunately, Pilkington does not follow that line of thought underlining a key variable: "extractive power" (ep) (247), which is integrated into the equation; a further aspect in the asymmetries in question $\mathrm{i}=\mathrm{dr} / \mathrm{y}$. ep. An analogously category, instead of "extractive", which could do the same job is "asymmetry": "the relative extractive power, ep - the threat - that the lender holds over the borrower also plays a role in interest rate determination. The lower the magnitude of the threat, the higher the interest rate will be, and vice versa" (Pilkington, 2016: 247).

13 (1 / 1 - MPC).

${ }^{14}(\mathrm{Y}=$ income, $\pi=$ profits, $\mathrm{W}=$ wages $)$.
} 
and consumption and excluding government and financial entities, GDP, equals the gross profits plus wages and salaries. ${ }^{15}$

Also, profits can be revealed with the following formula $\mathrm{I}+\mathrm{Cp}-\mathrm{Sw}=\pi \cdot{ }^{16}$ But this expression has excluded the possibility of examining the intrinsic potentiality of the antagonism in question, for example a recurrent recap of another cycle of higher wage demands by labour, since these shares or proportions cannot be ethically upheld or reasoned by the so called "marginal productivities" dictated by the "competitive" market narrative of marginalism. The agents "might not know" their actual standing income level with respect their past experience.

The expansion of the money mass, through the appropriate financial channels, to cover these advances is generally perceived as essentially "inflationary", a perspective from which Pilkington perhaps has not fully distance himself; a narrative which claims that all "inflation" is "too much money chasing few goods" or a "monetary phenomenon". Therefore, the "low-inflation equilibrium growth" or "unstable path of high-inflation disequilibrium growth" (198) specification tends to obscure those antagonistic moments characterized by the growth process. Although he discusses four types of inflation, "demand-pull inflation", "cost-push inflation”, "speculative inflation”, "exchange-rate inflation", which Pilkington says may overlap, he considers sufficient the assertion that it relates to a "complex phenomenon" (Pilkington, 2016: 175). ${ }^{17}$

Having "demolished" the "maximizing individual" or representative agent, Pilkington is required to incorporate a mechanism by which to explain the logic and practice of choice-decision related to investment. Equally having displaced the pertinence IS-LM model as a source of a unified horizon to reflect on the manner by which agents can be seen to undertake their investment choice-decisions (interest rate-investment), and/or financial markets, Pilkington is under an obligatory theoretical

\footnotetext{
${ }^{15} \mathrm{IR}+\mathrm{Cp}-\mathrm{SwR}=\pi \mathrm{R}$, profit formula with no government, (272). National income with taxes can be expressed as $\mathrm{Y}$ $\equiv(\pi-\mathrm{T} \pi)+(\mathrm{W}-\mathrm{Tw})+(\mathrm{T} \pi+\mathrm{Tw}+\mathrm{Ti})(210)$; taxes on profits, $\mathrm{T} \pi$; taxes on wages, Tw; and Ti indirect taxes. Therefore gross profits excluding taxes: $\mathrm{I}+(\mathrm{X}-\mathrm{M})+(\mathrm{G}-\mathrm{T})+\mathrm{Cp}-\mathrm{Sw}=(\pi-\mathrm{T} \pi)$; net gross profits, are the sum of $\mathrm{I}$, gross investment + net exports + budget Deficit + capitalist consumption - worker saving; $\mathrm{X}-\mathrm{M}$ net exports, exports minus imports; $\mathrm{G}$ - T the budget deficit, government expenditure minus taxes again, Cp consumption out of profits (capitalists consumption), Sw, workers saving. Notice that in the latter expression, the three bar denotation has given way to a causality implied by the two bar identity $(=)$ symbol which means that it is the left hand side where we find agents decisions changing the process in question.

${ }^{16} \mathrm{I}$ is gross investment, Cp consumption out of profits (capitalists consumption), Sw, workers saving (wages minus consumption of workers, or $\mathrm{W}-\mathrm{Cw}$; $(\mathrm{Y} \equiv \mathrm{E})$ Income in terms of expenditure, hence $\mathrm{E}(\equiv) \mathrm{I}+\mathrm{Cp}+\mathrm{Cw}$ and $\mathrm{W} \equiv \mathrm{Cw}+\mathrm{Sw}$. It follows that $\mathrm{I}+\mathrm{Cw}+\mathrm{Cp} \equiv \pi+\mathrm{C}+\mathrm{Sw}$; cancelling and reshuffling $\mathrm{I}+\mathrm{Cp}-\mathrm{Sw}=\pi$. The three bar notation $(\equiv)$ is a sort of "truism" (223), while a two bar notation is the identity symbol, which has "behavioural connotations" or a presumed causality, hence Pilkington's notation is a different way of distinguishing dependent from independent variables.

${ }^{17}$ Latin American structuralism discussion's, for which there is no space here, treats this "complex" phenomenon questioning the classic quantity theory of Money and its impertinence for the periphery; but unlike Pilkington, "inflation", is "always and everywhere" an antagonistic moment, a defiance of the "distributism" pattern which in actual fact Pilkington discusses, but on which he does not expand theoretically nor its consequences:

"inflation is fundamentally a struggle among groups for the redistribution of real income and the price level rise is just one outward manifestation of the phenomenon" (Furtado, 1954: 181) "inflation" (...) as we have seen is not, in its origins a monetary phenomenon. It results from the action of certain groups which pretend to increase its participation in the real income" (Furtado, 1954: 183).
} 
mandate to explain the indeterminate realm of "savers and investors" (Pilkington, 2016: 223) and the "varying interest rates" and investment projects, especially given the heterogenous and/or "kaleidoscopic" (Shackle) characteristics of the agents in question.

It initiates by distinguishing two processes, which Pilkington formalizes mathematically, whereby agents take decisions-choices, whether related to "financial investment sector", where liquidity preference $(\mathbf{L p}=$ Bear / Bull), plays a primary role and the "real investment" activity represented as "animal spirits" $\left(\mathbf{A} \mathbf{s}_{\mathrm{R}}\right)$, although he concludes with a more general formula subsuming the former within the latter:

\begin{abstract}
"the bear/bull ratio (i.e. liquidity preference) is actually synonymous with the velocity of money in the market in any given period. As the amount of bears increases relative to bulls, the velocity of money in the money in the market slows as those bears hoard money and the price of securities in that market falls. As the amount of bulls increases relative to bears, the velocity of money in the market speeds up as bulls increase their expenditure of money and the price of securities increases" (Pilkington, 2016: 241-42)
\end{abstract}

Certainly, breaking with "Keynesian" or "post keynesian tradition", ${ }^{18}$ he utilizes the notion of "animal spirits", reconstructing the concept by incorporating aspects of the "marginal efficiency of capital" pointed to by Keynes solely for the intent of pondering on the formal aspects of the process of investment. This line of argument implies that the notion of "liquidity preference" also has to be brought to shoulder the course of action of the agent. Thus to explain the activity of the "real sector", which corresponds to the "animal spirits" dominium: "animal spirits": ( (Ass) . (1 / i) . $\mathbf{Q}_{\mathbf{R}}$ $\left.=\mathrm{I}_{\mathrm{R}}\right)^{19}$ (animal spirits $\mathbf{A s}_{\mathbf{R}} ; \mathrm{i}$ = interest rate in that particular market; $\mathbf{Q}_{\mathbf{R}}$, expected profits; $\mathrm{IR}=$ real investment), Pilkington advances the idea whereby "animal spirits" are "the liquidity preference of the real investment market. They are, posed, the inverse of liquidity preference" (249). The "liquidity preference" refers to the ratio movement of pessimism/optimism, bidding, buying or selling bonds/assets; the yield-price vitality (Bear / Bull) in the "financial" market can be seen simply as the inverse of "animal spirits". Synonymous to the money velocity notion.

18 "Note that Keynes used this terminology in his Treatise on Money but we are using it in an entirely different way, one which incorporates Keynes' more mature ideas about liquidity preference (Keynes 1930). The present usage is more similar to the manner in which Joan Robinson used the terminology in her monetary theory but she abstracted away from the existence of bulls proper (...) an enormous step backwards" (...) the closest to the present usage is G. L. S. Shackle"(Pilkington, 2016: 269).

The formula would be 1 / [Bear / Bull] $\bullet \mathrm{M}=\mathrm{A} \bullet \mathrm{B}$; $\mathrm{M}$ is money; A refers to the price of the first but last bid of an asset / bond which is B. The formula for Capital Gains $t+1 \equiv A t+1 \bullet B t+1$. Therefore, $L p=$ Bear / Bull: $1 /[\mathrm{Lp}] \cdot M=A \bullet$ $\mathrm{B} \equiv 1$ / Liquidity preference $\bullet$ Money $=\mathrm{A} \cdot \mathrm{B} \cdot \mathrm{Lp} \equiv \mathrm{Bear} / \mathrm{Bull}$.

${ }^{19}$ Subscript " $\mathrm{R}$ " represents real investment in contrast to " $\mathrm{F}$ " financial investment: "If we refer to the actual money that changes hands due to financial transaction as financial expenditure or financial income, then we can say, again being careful to distinguish from real expenditure and income, that" (237) EF $\equiv \mathrm{IF}_{F} \equiv \mathrm{YF}_{\mathrm{F}} \equiv$ SF. In these cases, we are dealing with "financial expenditures", a bond ( $\left.\mathrm{E}_{\mathrm{F}}\right)$, or financial investment ( $\left.\mathrm{IF}\right)$, or if the receiving of an income (YF), financial income, or financial saving (SF), it's just an analogy to the real economy, it "does not add or subtract anything from it". 
The contrast between the notion of "animal spirit", viewed as the inverse (Bull / Bear) of the liquidity preference ( $\mathrm{Lp} \equiv$ Bear / Bull), means, paraphrasing Pilkington a rising impulse to increment of "real investment" enlarging new "productive capacities", borrowing money or "liquidate financial holdings, which culminates in new "productive capacity" (Pilkington, 2016: 24950), contradicting the liquidity preference ratio which entails a reduction of acquisitions level by financial investors protecting its purchasing power by amplifying its "liquid assets" or cash.

Perhaps the distinction between Lp = Bear / Bull and ASR formula, financial and real investment respectively, becomes an important necessary qualification in the investment process for those economic formations in the "centre" which exhibit an important multi-layered and "deep" bond-assets and "stock-market institution" and all sorts of money substitutes (Ms) which cannot be generalized to reflect the investment process in the peripheral countries. In certain center or core economic formations, these financial underpinnings are crucial to the investment choice-decisions patterns, the rise of the hegemonic role of the "bullish" "vitality" of the market, whether "financial" or "real" forms part of the changing transient antagonistic conditions between and among agent, or firms.

Pilkington insists that the agents in question (Bears / Bulls), are "people", optimistic-pessimistic about a future bonds-assets yield-price increases (decreases), ${ }^{20}$ but for the critique that follows, I underline the notion that the reference to "people" as those whose pathway between "Bear" to its opposite "Bull" (indeterminate in time and process), are not necessary "humans individuals".

It refers to movement of the "ratio": proportions of changes those flipping from one position to another, a consequence of a diverse set of heterogenous-kaleidoscopic agents, but most of which are not "people", among whom we can mention are great corporate entities or bond-stock associations and their respective "algorithm's" coupled to decisions/options:

\begin{abstract}
"in what proportion those in the market are net selling and to what extent they are net buying. The manifestation of the bulls and bears represents the market as a whole liquidity at a given moment in time. As liquidity preference rises bulls turn to bears and as it falls bears turn to bulls. So, the liquidity preference rising leads to a heavier weighting of bears in a given market than of bulls and vice versa or: (Lp $\equiv$ Bear / Bull)”. (Pilkington, 2016: 239) "'21
\end{abstract}

\footnotetext{
${ }^{20}$ Pilkington's explanation underlines a crucial point at issue: the contrasting logic of the price of bonds with respect stocks: "the price of a bond is inversely related to the interest rate or yield on that bond. Thus when the price rises/falls, the yield will fall/rise. This is, however, not the case with stocks. Stocks do not have interest rates per se. Rather they pay out dividends and the relationship between the price of a stock, and its dividend is by no means simple. The reason that economists historically discuss bonds rather that stocks is because of the simple price/interest rate trade-off that characterizes the market. The stock market is a far more complicated beast but the basics can still be understood by utilizing the liquidity preference theory. Just remember that while when the price on a given bond rises, its interest rate declines while when the price on a stock increases its dividend should not be directly affected." (Pilkington, 2016:267)

${ }^{21}$ The reason which explain why the capital market horizon does not reflect a hurricane of untamed forces, has to do with "social norms within investment communities. Optimism and pessimism tend to come in waves (...) and during these waves, swings are somewhat bounded. But there is a deeper explanation, and it is one that economists like James Steuart and Karl Marx new well: the interest rate is a question of distribution grounded in legal, social and political norms. The interest rate - or the rate of return on accumulated wealth- is determined by the relative social power of creditors" (Pilkington, 2016: 246).
} 
The "animal spirits" is displayed through the work of Shackle "kaleidoscopic" notion: a diverse and non-determinant mode of calculating (assessing), modes of investment projects, the "equiprobable" case of certain future events occurring is excluded, and stresses the "potentially infinite" (Pilkington, 2016: 286) events or outcomes, which means that we are in a completely "different space" to the "dice" or the "coin" illustration of "chance" implied by certain models of econometrics or schools whether Bayesian ${ }^{22}$ or not. Shackle (1966) is brought to enlighten the "subjective" nature of our evaluations "human imagination and storytelling comes to the fore, we are no longer in a world of the probable, rather we are in a world of the possible" (Pilkington, 2016:, 286-87, citing Shackle, 1996, 94-95). The "individuals" "uncertainty" in question under uncertainty, can nevertheless separate "sense from nonsense" (Pilkington, 2016: 287), putting aside conjecture and imagine alternative situations, which is defined through the work of Shackle as "bounded uncertainty" ${ }^{23}$ (Shackle, 86 quoted in Pilkington, 2016: 287) which in turn reminds us of Simon's use of "bounded rationality" (Hodgson, 2004).

Before describing the description of the formalization process by which "animal spirits" $\left(\mathrm{AS}_{\mathrm{R}}\right)$, investment-profit is realized, in bookkeeping terms, its necessary to represent the notion of profit in question.

The "animal spirits" $\left(\mathrm{AS}_{\mathrm{R}}\right)$ are the consequence, the result, of the ratio movement of Bulls to Bears in the market for "real investment", which Pilkington formalizes:

$$
\begin{aligned}
& \left(\text { Bull } / \text { Bear }_{\mathrm{R}}\right) \cdot\left[1 /((1 / \mathrm{M}+\mathrm{Ms}) /(\text { Bull } / \text { Bear }) / \mathrm{A})_{\mathrm{F}}\right] \cdot \mathrm{Q}_{\mathrm{R}}=I_{\mathrm{R}} \\
& (\text { Pilkington, 2016: 250) }
\end{aligned}
$$

or

$$
\begin{aligned}
& \left(\text { Bull } / \text { Bear }_{\mathrm{R}}\right) \cdot\left(\mathrm{i}_{\mathrm{it}}+\mathrm{T}_{\mathrm{c}}+D_{r}^{e}+\Delta i_{r t}^{e}\right) \cdot \mathrm{Q}_{\mathrm{R}}=I_{\mathrm{R}}{ }^{24} \\
& (\text { Pilkington, 2016: 271) }
\end{aligned}
$$

\footnotetext{
${ }^{22}$ The book also presents a well prolonged theoretical discussion, between different "schools" of econometrics and the role given to "objectivity" of the calculus in question.

${ }^{23}$ Pilkington devotes much space to discuss the notion and its differences between Keynes and Knight; on his part Danby (2017: 158) merely distinguishes the Keynesian idea as necessarily an "ontological" condition; see also Hodgson (2011). ${ }^{24} \mathrm{irt}$ (overnight target interest rate), Tc transactions costs for borrowing money and Lpirt stands for the liquidity preference in an IRT market, in which "the central bank does not intervene directly in these [financial markets] by engaging in assets purchases" (244), hence the interest rate $\mathrm{i}=\mathrm{irt}+\mathrm{Tc}+$ Lpirt . The interest rate thus determined, is the consequence of irt (overnight target interest rate), Tc transactions costs for borrowing money and Lpirt stands for the liquidity preference in an IRT market, hence the interest rate $\mathrm{i}=\mathrm{irt}+\mathrm{Tc}+$ Lpirt (Pilkington, 2016: 245). But "liquidity preference" under the IRT market liquidity preference has to take into consideration the Default risk (D_r^e) and the expected change in the overnight target interest rate, hence Lpirt $\equiv \mathrm{D}_{-} \mathrm{r}^{\wedge} \mathrm{e}+\square \mathrm{i} \mathrm{rt}^{\wedge} \mathrm{e}$ ( $\square=$ proportion of change). Therefore, the expression irt $+\mathrm{Tc}+\mathrm{D}_{-} \mathrm{r}^{\wedge} \mathrm{e}+\square \mathrm{i} \_(\mathrm{rt})^{\wedge} \mathrm{e}=\mathrm{i}$, means that as the number of bonds grows money mass expands, which in turn entails the issue money's risks, whether to keep idle or invest it.
} 
Pilkington launches the discussion of investment to an end note and in which he is aware of a similarity with something "like an 'accelerator principle"" to think the notion of the "rate of investment" (Pilkington, 2016: 271).

According to him, the

"accelerator principle performs rather well empirically but it fails to explain why investment every now and again simply falls. This can be explained much better using a framework that integrates liquidity preference and animal spirits. We should also note that while the above is a good way of thinking about the economy, it is not entirely accurate. After the 2008 financial crisis and the subsequent recession, corporate profits in the USA soared due to the large government deficits that were being run at the time. Nevertheless, investment was extremely slow to pick back up. This was because the firms were able to meet their present orders without needing to expand their productive capacity, and so they turned to wash their profits back into the financial markets. In Keynesian terms, we might say that the marginal efficiency of capital was very low relative to the going interest rates in the financial markets at the time. This example shows quite clearly that it is to oversimplify to say that profits determine investment in some mechanical manner. (...) We have only laid out the above provisional account as a sort of guide which is by no means definitive. In order to understand the real nature of investment, one must be appreciative of the kaleidoscopic nature of investment decisions in capitalist economies and be prepared to fully engage with the 'state of the news'. This is why economics can never aspire to being a 'hard' science like physics or chemistry. The subjective and evolutionary element therein is simply far too great" (Pilkington, 2016: 271-72)

\section{3."Ruling the Roost". ${ }^{25}$}

The title of this section, intentionally aims to provoke certain ambiguities of Keynes famous aviary image by which he advances the argument explaining which particular "asset" becomes the dominant bench mark for examining potential investment strategies, which is also a distinctive aspect when analyzing diverse economic formations, or the center-periphery power asymmetries, in other words, that which appears a clear cut choice decision response on the part of certain agents, its belied by the context and power conundrum. The "ruling" and "rules" dichotomy implies some explicit dominium and following instructions; an evaluating agency and a "policing" practice, hence the role of the FMI in most negotiations to restructure loans-debts, for example, and/or credit rating agencies.

The "broader conclusion" is that: "the interest rate is ultimately determined by the relative power of creditors in a society" (Pilkington, 2016: 270).

"Since the loan shark operates outside of the law, his extractive power is higher than that of the bank which operates inside of the law. This means that interest rates are always determined by the prevailing structures of the era. (...) always precede the existence of capital markets." (Pilkington, 2016: 247)

25 "For it may be that it is the greatest of the own-rates of interest (as we may call them) which rules the roost (because it is the greatest of these rates that the marginal efficiency of a capital-asset must attain if it is to be newly produced); and that there are reasons why it is the money-rate of interest which is often the greatest (because, as we shall find, certain forces, which operate to reduce the own rates of interest of other assets, do not operate in the case of money)." (Keynes, 1936: 223-24) The General Theory of Employment, Interest and Money ; New York, Harcourt, Brace and Company. 
Bankruptcy laws represent the embeddedness of "legal frame works" (Pilkington, 2016: 248), there is always a regulatory regime, customary, and / or traditional. Capital markets function because there are all sorts of regulatory regimes.

\begin{abstract}
"The key determinate of interest rates is the relative social power of creditors. We as society determine this relative social power. If a society is set up in such a way that the creditors control the mechanics of power then then the relative return on wealth should be low, then it will be low. What is more, there is no 'market rate of interest' prior to these arrangements already in place. Certainly, there are various market rates of interest within a given legal-institutional but there a cannot logically be any market at all prior to the legal institutional arrangements being in place. (...) because mainstream economics can say nothing about the relative power of creditors in society, (...) their theories are still completely irrelevant because they say literally nothing about the relative power of creditors in the economy" (Pilkington, 2016: 248-49).
\end{abstract}

Power asymmetries between the center-periphery antagonism, focused within the context of trade policies, are equally central to Latin American perspective, initially defined by Prebisch as the "Ricardian loss" probe, which unfortunately, does not receive much space in Pilkington's book: one chapter, the shortest, bringing once again to light a certain undecided theoretical aspect of his work, the antagonistic character and power driven nature of the notions of agents and their milieu. In "Non-Dogmatic Approaches to the Economics of Trade", the critique of the relative comparative advantages of the international "division" of labour doctrine, underlines once again the importance of "uncertainty" to deliberate on investment decisions and their diversification: you "should never put your eggs in a single basket". This is coupled to revealing the shallowness of those arguments which sponsor "free trade" under whatever circumstance. Therefore, that which is taught as "the theory of comparative advantage", is portrayed as David Ricardo's struggle in the 19th century to promote the "free trade" strategy by the then ruling "Empire". But today in the so called "promotion", by the "Washington Consensus", of trade between "open economies", Pilkington representations of its consequence is underlined by the simple example of the role of production specialization on those products with which a country performs better than its trading counterpart, allegedly propagating a higher total product for those economic formations involved, a perspective which hides a series of unsustainable presuppositions, which "development policies" should challenge, especially in the periphery.

The criticism stresses the distance, once again, between the models and the "abstract world of ideas" (Pilkington, 2016: 326). Models' of comparative advantage, assume full employment in both entities/countries implicated, and the existences of unemployed resources can be put to work literally "cost-free". Free trade deals generally bring about the loss of employment and the narrative in question insists that these loses are "matched by gains in a new export sector" (326), synthetica1ly, it resuscitates "free market clearing" arguments as well as the assumption that a more dynamic efficient productive sector will materialize. But, as economic formations not only in the "center" 
and especially those in the "periphery" have found out:

\begin{abstract}
"it becomes by no means clear that if a factory geared towards domestic production closes down in Detroit due to a free deal, it will be replaced with a new factory geared towards export production. A whole host of factors will have come into play here to rebalance the economy from this shock and ensure that it reaches some sort of equilibrium; otherwise, the result will simply be unemployment and a serious downward pressure on wages in the higher wage country" (Pilkington, 2016: 326$)^{26}$
\end{abstract}

Pilkington's USA example elaborates the narrative on the importance of the positive effects of free trade and open economy generating a higher level of efficiency around the world, but which simultaneously and collaterally undermines "worker organizations" through unemployment augmentation which in turn induces some form of stagnation in effective demand, debt rise and instability. Once again, the comparative advantage doctrine, assumes away institutional factors, resuscitating "flexibility" and perfect factor substitution. This theory is certainly "static" in the sense that the specializing trajectory in certain sectors or segments inhibits their future development into higher technological areas. Ricardo's Portugal/Britain open trade example (cloth/wine respectively), obviously was pondered from within the British empire perspective, which might have ruined an impending "textile" industry. The example on protection policies in the USA is a clear case which demolishes any sort of "level playing" field by limiting imports and thus generating local positive effects for local companies.

The dominium of the aviary image of the dominant "rooster", ("ruling the roost"), in the context of "open economies" and "free trade" in a world of multiple antagonistic "exchanges" obscures to say the least the latter configuration. Hence "free trade" specialization can become a very negative and damaging long run consequence in certain areas or centre countries too. In the periphery, the prices of its export (primary) products exhibit a haphazardly tendency, which, and contrary to centre economic formations, have limited power trade mechanisms by which to counteract internally and externally a "purchasing power" loss, or income level vis a vis the "external shocks".

Prebisch's arguments on these aspects, during the early 1950's are clearly reflected in the negative consequences for the balance of payments and the functional the distribution of income in the periphery. The predominance of policies for a "inward growth" strategy vis a vis the one sided "export driven" perspectives of "pre-war Second World", implied recovering the importance of the "multipliers" effect of local capital investments.

${ }^{26}$ No space to touch on Pilkington's, rejection of the notion of equilibrium or Latin American structuralism critique, but Nadal's, (2004), deconstruction of the mathematics in question is counterpoised by Debreu dictum that: "in proving existence" (...) "one is not trying to make a statement about the real world, one is trying to evaluate the model" (Debreu, 1987: 149, in Duppe Till y Weintraub E. Roy, (2014). For a general appreciation of the concept equilibrium see: Russett, (1968). 
Once a period of deterioration of the terms of trade sets in, the periphery's limitations to sustain external payments to cover not only certain aspects of current but also capital account to maintain certain levels of imports is underlined, a thesis which again, during the 1970's, in the Eurocentric discourse is tangled (sorry for the pun intended) to the name of A. Thirwall ${ }^{27}$ thesis on the "balance-of-payments-constrained growth models".

Pilkington is all for "diversification" of the economy, which allows the economy to withstand the "unforeseen swings in the supply and demand of certain goods. Again, we should always remember that it is not a good idea to put all one's eggs in one basket lest that basket fall to the ground." (Pilkington, 2016: 328).

Nonetheless, first of all, its urgent to displace the aviary vocabulary, and the "chicken run" images, which is not conducive to reflect the antagonistic characteristics of the realm in question. Previously we mentioned the semblance related to the inadvertent "dropping the basket", which only mask's the potential power asymmetries among some countries (agents) to undertake and sponsor policies to counteract the negative consequences of the reduction of purchasing power of its exports and hence its imports level capacity. During the 1950, and 60s, the movement to construct a sort of "buffer stocks" to stabilize prices for certain primary goods like, coffee, cocoa, sugar goods, was defeated during the 1980's neoliberal's narrative of "open economies" and non-intervention in the so called "market" by the State. Although the encouragement of export policies for certain sectors was not an antithesis to an inward led development policy proposed by Prebisch and Latin American structuralism, the struggle to undertake reforms in the periphery to selectively open certain sectors of those economic formations, became prohibited during the external debt renegotiations during the 1990's negotiations.

Terms matter (centre-periphery antagonisms) specially when the aim is to explain agents's behavior and outcomes vis a vis each other during their "interaction". The early illustration posed in the book by Pilkington, on the outcomes of certain football spectator's behavior, forcing or determining the "upright" position to those behind them if they stand up, evades the consideration that the event reflects a potentially antagonistic confrontation with those spectators that do not want to see the game in an upright position and worse-case scenario, those groups of individuals which have "organized themselves" to act otherwise as a "unified" agent, bringing to light the indetermi-

\footnotetext{
${ }^{27}$ Again, no space here to describe Prebisch's theoretical vocabulary during the 1950's which would certainly displace the "odd couple" narrative repeated in Eurocentric academia in the 1970's with the so called "Thirwall - Prebisch" thesis, in Lopez words: "the Prebisch - Thirlwall notion (...) has become a workhorse in Keynesian-inspired open-economy macroeconomics. Its main message is that when exports grow (or when the import elasticity of output falls), private demand is stimulated. Besides that, note that growth of exports induces growth of imports, which, however, is lower than the original growth in exports, such that the government has room to implement expansionary demand policies without endangering the trade balance." (Lopez, 2018: 337). Furthermore, the insistence in recent decades with policies for the periphery, which exclusively concentrates the "export driven" sectors as the only powerful multiplier dynamism for growth vis a vis local capital development investment can be questioned (see, Perrotini; Vázquez-Muñoz, (2018).
} 
nate heterogenous nature of the agents in question, "individuals" or a "unity of spectators", both of which require some sort of deliberation choice-decision moment. The process might generate a collective "agency", pushing, shoving and threatening those in front if they don't sit down, it's an undecidable and contingent "situation"; we cannot discern in advance what response the behaviors in question will ensue, requiring examining the historical data, otherwise, we would be receding into the predetermined rational actions of the "representative agent of marginalism" which Pilkington demonstrates as unviable.

Although Pilkington, as mentioned previously, is not consistent on the vocabulary and its tone, since he advises awareness of the "institutional nuance" (Pilkington, 2016: 329) of "free trade" which he acknowledges: "free trade is an inherently political issue: what political forces within the countries in question are for the free trade policies and what political forces are against them" (Ibid., 329):

\begin{abstract}
"What changes will opening up an industry to free trade have in the countries in question? Is there reason to believe that the labor that loses employment will automatically find it elsewhere and will the jobs be of equal quality? Are we making a country too reliant on a single good when we open them up to free trade and enforce specialization? What effects will the opening up of a country to free trade have on income distribution? (329) (...) In order to understand the agenda behind any trade policy at any given moment in time, you must examine it in critical detail. What free trade dogma does is it tricks economists fooled by their own simplistic narratives into becoming propagandists for whatever powers-that-be want to impose on various countries at any given moment in time? (Pilkington, 2016: 331).
\end{abstract}

Accepting Pilkington's dictum that "free trade" is not always "bad", and contingent on the political and economic forces in question, a "development strategy" is of prime importance in countries which are at the extreme end of the asymmetric power contingent chain effect, which again cannot be examined independently of the specific power asymmetries in question: countries and enterprises (agents) involved, the range and capacities of debt, evaluated by agencies in Center countries'. The periphery's product's future, or purchasing power incomes is equally examined, and "policed" with WTO rules, which limit the pertinency of using the "market" narratives as the best pick of the bunch to elaborate the long and short view of the investment projects. Equally, the sole idea of "free trade", as well as "opening up a country", accepts most of the presupposition of the "Ricardian Zealotry", evaporating the asymmetric power relationships which world trade organizations enforce systematically and sometimes even against the trade conventions, a consequence, as said before, of the power the asymmetries between the nations in question. It's in this discussion where Pilkington's strategic critique of "Ricardian Zealotry" might miss the mark, since he assumes a "consensus", "quite terrifying" (Pilkington, 2016: 330) among economists, about the positive role of "free trade". Although it's very easy to agree with Pilkington critique of the "Ricardian Zealotry" in question, which underlines the substantive childish theoretical presuppositions originating in "market efficiency" and EMH arguments, the apparent "consensus" by Eurocentric academia its 
contradicted by Latin American economic discourse as seen previously. Sharing Pilkington "exasperation" and "shocking" disbelief of the theoretical vocabulary and preaching when the issue of "free trade" is discussed by Eurocentric economists, this opinion is not unanimous as the above has shown among "economists" in the "Periphery", despite its hegemonic role in most of the economic reforms over the last three decades by the Latin American governments.

To underline my argument, and perhaps reinforce Pilkington's use of Krugman to that effect, I may concur with most of the limitations which the "patronizing tone" of Krugman position generates in the theoretical discussion on the status of the "comparative advantage" narrative, but then Pilkington himself could be under the same insular sway by not taking into consideration the distinct and alternative discourses outside his own geographic milieu, notwithstanding his allusion to the struggle by French students to reform the economic discipline.

Krugman's theoretical evolution shows just as well the "exasperating" institutional conditions of the profession in question mentioned by Pilkington, in which confessions on theoretical wavering's are not really made to count. Let's not forget Pilkington's presentation of the ambivalent nature of most of Krugman's appreciation and position on the IS-LM model discussions, with the "comparative theory" narrative, and the "ambiguous nature" of the author's ideas. Krugman's discussion and propagandist thesis on "Ricardo's difficult idea" was followed (and I am not going to say paradoxically, because it's exactly the practice of the economic profession which I wish to underline), by a text, in the course of which it's claimed, as previously cited, A. O. Hirschman's work on development theory, "proves" that "equilibrium theory" was wrong and "the theory of economic development was correct" (Krugman, 1997: 29). And yet there seems to be not even a hint or impression of the theoretical consequences which should follow from this revelation, for his own previous "decades" of work or the economic profession at large for that sake. I am not just implying the "limited" knowledge of Hirschman's work ${ }^{28}$ by Krugman, rather it relates to the inexistence of any sort of theoretical reconsideration which such a recognition should generate, and especially because "disequilibrium economics" presupposes a totally different set of notions about the agent's conditions of existence and their perspective to undertake certain decisions-choices.

Hence "desequilibrium economics" implies taking seriously the terms of trade and their consequences specially for the periphery vis a vis the center. If we retrieve Pilkington's final profit equation, with no government ( $I_{R}+C_{p}-S_{W_{R}}=\pi_{R}$, ) (Pilkington, 2016: 272), and twist it a little, national income with taxes can also be expressed as $\mathrm{Y} \equiv(\pi-\mathrm{T} \pi)+(\mathrm{W}-\mathrm{Tw})+\left(\mathrm{T} \pi+\mathrm{Tw}+\mathrm{T}_{\mathrm{i}}\right)$ (Pilkington, 2016: 210); and global profit as: $\mathrm{I}+(\mathrm{X}-\mathrm{M})+\mathrm{Cp}-\mathrm{Sw}=\pi$, which are the sum of $\mathrm{I}$, gross investment + net exports + budget Deficit + capitalist consumption - worker saving; $\mathrm{X}-\mathrm{M}$ net exports, exports minus imports; $\mathrm{G}$ - T the budget deficit, government expenditure minus taxes again, $\mathrm{Cp}$ consumption out of profits (capitalists consumption), Sw, workers saving. Notice that in 
the latter expression, the three ( $\equiv$ ) bar denotation has given way to a causal process implied by the two bar identity (=) symbol, which means that it is the left hand side where we find agents decisions changing the process in question.

The antagonistic "trade" relations between center and periphery are hidden somewhat, since the periphery's export volume is concentrated in a reduced number of products, generally "primary" products, although not necessarily. Therefore income, which in distinct periods tends to display a deterioration of its value in terms of those it acquires from the center (industrial goods), becomes the source generating the series of "devaluations" and "higher import prices" and not necessarily a financial mismanagement. Aspects of which, in Eurocentric academia, Prebisch's name is joined to Singer. Given the Center-periphery power asymmetries, ${ }^{29}$ it's the periphery which modifies its "prices" or "costs" during the downturn of the cycle, while in the center, a better organized labour force manages to retain certain levels of income previously reached, and therefore manages to keep those "fruits of technical progress", an entitlement, to which, it must be emphasized, is deservedly acquired in view of their previous toil and sacrifice, but a process towards which the periphery wants access through a selective process of social and technical transformation, by a variety of industrial and social reform policies. The deterioration terms of trade of the periphery vis a vis the core countries, in Prebisch's view is not an "iron law" (Prebisch: 1951b; 195a) 31 ; the wave, ondulatory "movement - reality" of "capitalism", the upswings and downturns, implies taking into consideration aspects of the balance of payments and the trade relations as intrinsically "uncertain" and volatile, which in the last instance are the consequence of time disparities among and between economic formations (centre-periphery) and the productive and circulating realms.

\footnotetext{
${ }^{28}$ On Hirschman see Mallorquin (2011, in Márquez; Soto; Záyago, (coords 2011).

${ }^{29}$ Once more the "Prebisch-Singer" thesis, requires a theoretical "decoupling" process: the "deterioration" process appears in his writings during the early 1930's and the vocabulary "center-periphery", it is quite dissimilar to Eurocentric - Anglo-Saxon academia notions of trade between industrial and primary producing countries.

${ }^{30}$ Please take note that we don't use the term "unequal", but which does not mean the absence of imperialist policies.

${ }^{31}$ After the appearance of various texts (Prebisch, 1949b, 1950, 1951) where Prebisch presents these aspects in detailed fashion, in a course of lectures in October of 1951 to the Training Center of Latin American in programs and agricultural projects and related subjects, he explicitly denounces the then misinterpretation of his posture: "I was made responsible of having formulated an immanent law of the process of economic development by which the prices of primary products tend to depreciate in relative terms with respect those of industrial products. I have not formulated any sort of such immanent law, but simple I called to the attention on the phenomenon that has occurred in a determinate period of time under the pressure of certain forces. We don't know what will occur in the future, it depends on a series of factors" (Prebisch, 1951b: p. 6-7), "Problemas del desarrollo económico en América Latina", Third Conference, 25 of october 1951. Spanish readers should have known better, english readers on the other hand, had to deal with a relatively shabby translation of (1950 and 1951). As a rule United Nations documents translate them into english and french; "Crecimiento, desequilibrio y disparidades: interpretación del proceso de desarrollo económico",in: Estudio económico de América Latina, 1949 - E/CN.12/164/Rev.1 - 1950 and (1951) Problemas teóricos y prácticos del crecimiento económico, CEPAL, México, 28 mayo E/CN.12/221. On the other, the classic text (1949b), El desarrollo económico de la America Latina y sus principales problemas E/CN.12/89 (May), under a very close scrutiny by the U.S. government fared much better in english. Perhaps Prebisch, given the load of work and strain under which he was working did not check the translations.
} 
Today's mode of organizing a selective "open" devaluation process among and between diverse economic formations, centre-periphery, does not allow for much room for an autochthonous adjustment without penalizing "development" policies in the periphery (e.g. Nadal, 2004a). The center-periphery power asymmetries are related to the existent, although challengeable, constraints imposed by certain historical trajectories, requiring reconfiguring the previously diverse and heterogenous conditions of existence of trade and productive exchanges.

Furthermore, the periodical relative reduction or purchasing power "loss" of income by the periphery given its trade and commercial links, contributes negatively to its "external" balance sheet, and capital account, requiring borrowing from the "center" at a certain rate of interest, with a currency unit (generally the dollar) as an "asset" whose value as Keynesian's say, "own rate of interest", oscillates, not only with respect of the periphery's monetary unit but also in reference to other international standard currencies (euro, yuan). As we know from Pilkington's presentation, local and international interest rates are the product of power asymmetries' themselves; different trade zones and economic formations (center - periphery alike - agents) aspire to "control" through their portfolio payment's management which is articulated and pegged to the value of the dominant of highest most used currency in the zone in question. Corporations, commercial enterprises and countries have to fine-tune their payments to the changing nature of what Keynes described as the "rules of the roost" antagonism, (Keynes, 1936: 223) or the asset/commercial entity whose value level "disciplines" a ranking order by which debts and investments are calculated (Minsky, 1986). Recently it has been argued that there is in existence an asymmetric "hierarchy" of international monetary anchor-units (dollar first, euros second generally and Japan's monetary third in its region), ${ }^{32}$ a ranking order, once again, an asymmetry of power relations between and within center and periphery dominating the mounts and shares worldwide used of the international currency which clears the great part of the "transactions".

Unlike the post second world war international agreements of Bretton Woods, which pegged on "dollar-gold" the currencies in question, the actual open and antagonistic struggle to occupy the "rule of the roost" position, or convert to a certain anchor currency preference as the unit for trade, and therefore debts, its "normal" to encounter contingent and transient periods whereby countries balance accounts change dramatically, as the unfortunate image goes, a variety of agents transform their assets and "fly to safety" from the periphery headed towards the center, anchoring its portfolio value set into those international monetary currencies considered of the highest relative

${ }^{32}$ Rogerio P. Andrade \& Daniela Magalhães Prates (2013); Bruno De Conti, Daniela Magalhães Prates (2018); Luiz Fernando de Paula, Barbara Fritz \& Daniela M. Prates (2017); Daniela Magalhães Prates, (2017); Daniela Magalhães Prates \& Luiz Fernando De Paula, (2016); Meireles (2016) 
"value". ${ }^{33}$ Once again, displacing the "aviary" metaphor, it's the "monopoly" on the possibility to create and use the dollar, by the U.S.A, lowering transactions costs internally and externally, which forms the basis for its dominant international role as a unit of account: fewer negative dangers and risks of the so called "flight to safety" conundrum, despite all vulnerabilities and impending crisis intimated since remote times, by the economists of the Bretton Woods era (Triffin, 1960); (Kregel, 2018); (Minsky, 1986).

Since the 1980's debt "crisis" sustained by the periphery, the IMF has become (which was not its original role $)^{34}$ the "financial and monetary agent" of the private Banks in the center to negotiate debts and new loans vis a vis the periphery, which unshackled those entities (corporations) individually from assuming the responsibilities and risks of a bad lending and low insurance predispositions when dealing with the periphery. On the other hand, the periphery's representation in the administrative echelons of the IMF, given its very low voting rights has limited areas where it can induce certain discussions to push for a reform of the institution or a worldwide financial reform, despite very important economic transformations within the appearance of a number of countries like China, Brazil for example.

\section{9. "You want the social"?}

It's in a note at the end of the chapter 10 where we find Pilkington contemplating the reasons of the persistence of why "people" or economists hold "marginalism" as a worthy academic enterprise, despite information to the contrary. He makes references to some sort of explanation, relating to a certain "fatal attraction" between men, their belief, with "certain types of theory" (Pilkington, 2016: 319), and points to the fallacy of struggling to convince people otherwise:

\section{"it becomes obvious that you really cannot convince people who adhere to these theories that they might be wrong. So, the goal becomes rather to allow a space within economics for those that think they might be and see who, in the aggregate, produces more functionally useful work." (Pilkington, 2016: 319)}

But this is the nitty-gritty of the matter of the dispute as to "who decides?" which are the mechanism's available for that undertaking?, the construction of such a contested space is what is at issue, it's a political issue on which Pilkington is ambivalent, and which simultaneously acknowledges its existence by demonstrating the hegemonic struggle which "deconstruction" implies: a decision of some form, of some type of "coercion", exclusion/inclusion or rule with which to

${ }^{33}$ See also Regantiquili, (2016).

34 (Furtado, 1989; 1981); Ugarteche (2014); Danby, (2017); Helleiner (2014). 
uphold the space in question. It's commendable Pilkington's use of the "justice model" example as a contesting ruling behavior resolution procedure precisely because it reiterates the importance of undertaking a "judicious democratic decision".

Hence the gross profit equation and its sources is the manner by which Pilkington displays the question, which can be seen an undecided ethical-political problematic, since according to Pilkington we are not sure the issue is "political" or "partisan" (Pilkington, 2016: 219). Having posed "profits as a moral dilemma" (Pilkington, 2016: 211), the narrative transforms both, Marx's and marginalists" into a "subjective" "war of interpretations" story, steering clear from aiming for an "objective" description of their respective notions of profits or it's existence. Pilkington does mention the unsustainable and contradictory version of the marginalists's story of the non-existence or, un-normal "presence" of profits in the literature, and/or the cuasi orthodontist Marxist "extraction" metaphore of surplus labour power by the capitalist. And yet "hidden", in a profound note number 13 at the end of the chapter 8 , we are offered a brief theoretical description which questions the notion that income "is distributed in line with the marginal productivities of capital and labour" (Pilkington, 2016: 218). The mention of the Cambridge Capital Controversies underlines precisely the narrative, which should had been introduced into the text given it's importance:

\begin{abstract}
"They were trying to demolish any deterministic distribution theory and put forward the idea that the distribution of wealth in any given society is a moral, political and historical issue. This opens up the space for us to have a real discussion as to whether any given income distribution is fair or not, and it prevents the zealots from telling us that left to itself the system will largely determine this distribution in some sort of efficient manner which, if we tamper with it, will result in chaos and disorder. For a decidedly politically partisan view of the question, although one that does succeed in getting to the heart of the issue in a way that economists are generally unable to do see [the text of] (Ackerman 2014). (in Pilkington, 2016: 219).
\end{abstract}

"the competitive market economy no longer contains any necessary mechanisms pushing the various wage rates or the profit rate to any determinate level. Rather, history and custom, as well as politics, laws and struggle, will determine who gets what. It's a system of grab what you can" (Ackerman 2014 in Pilkington, 2016: 219)

If "wage income and profit income are merely two types of income" (Pilkington, 2016: 107), there is no necessary inverse relation between those incomes, which was precisely the reason of introducing the name of Kalecki in the story. Marx's account of the process may well be branded as "metaphysical" (Prebisch, 1949a: 417) given its value/price dichotomy, but which should not be the excuse to dodge the mother of all issues: the asymmetries' of power among and between agents (labour-capital; capitals vis a vis capitals), which evolve through the mechanisms by which certain conditions of the productive and circulatory are held: the possession in separation thereof. That possession in separation of certain conditions of the productive among and between diverse heterogenous agents becomes the foundation of what is called the "market", the links of the units or production among themselves and to labor power, are the consequence of a series of contingent 
rules and historical practices which in turn can explain the absence of a "representative rational agent". The antagonism between and among agents in their struggle to determine its "prices" generates, instead of a general "rational" mechanism, a multiple heterogeneous universe of agents with no guaranteed representative agent kingpin, required by "marginalism" and its "system" of equilibrium. On the other hand, the same antagonism, within the multiple and heterogeneous agents, breeds a variety of alternatives (a heterogeneous milieu) in which agents have to organize the production process, under no necessary logic or relation to the evolution of the "organic composition of capital" on which Marx's narrative depends. Not the consequence of "competition" nor its opposite "monopoly", but rather the outcome divergent profit margins and prices, each an outcome of the contingent configuration of asymmetric power relations among and between agents, "degree of monopoly" in Kalecki's term.

In occasions, Pilkington's narrative is not scrupulous enough to distinguish the degree to which the "distribution of income" implies a political partisan examination which supersedes "moral aspects", although he does assert that the "relationship between wages and the mark-up will determine to what extent income is distributed between wages and profits" (Pilkington, 2016: 211).

But the use of the notion of the "mark-up" amplifies the conundrum, the implied antagonism, which is the mechanism we are trying to underline, but lies hidden with the reiteration that it's just a "conventional" contingency.

\begin{abstract}
"Conventions are not immutable. They are subject to moral or ethical evaluation and the political change that may result from such an evaluation. When discussing profits (...) we can never lose sight of the moral dimension. Marx and the marginalists sought to hide this moral dimension behind a veil of what can only be described as metaphysics, in the most pejorative form in which that word can be used. The marginalist sought to justify the existence of profits as a sort of transitory phenomenon stimulating entrepreneurship that had nothing to do with power or underlying social relations. Marx, on the contrary, completely ignored that profits might stimulate entrepreneurial activity and instead insisted wholly on power relations. His implicit working premise was that only labour adds value to goods produced and those who come up with the idea and take the risk in putting it into action by investing and hiring workers are vile leeches. (Pilkington, 2016: 212)
\end{abstract}

For Pilkington both narratives are fictions to justify their divergent perspectives, since each has an "element of truth" (Ibid.,212). Therefore, if entrepreneurship is encouraged by profits, they are also the consequence of power asymmetries which are organized by the social relations in question. Simultaneously, both aspects of the account are considered as pertinent, endorsing their own particular "a priori political position" (Ibid., 212). On the one hand marginalists insist on the fair and efficiency of the free market organization, while Marxists, highlight the importance of abolishing profit so that a free society can arise. While Pilkington rejects the idea of generating a new "gospel" (Ibid); his own task is to propound these postures as merely subjective "moral judgements" (Ibid.,) and should not be surrendered since it reflects "our ability to be individuals" and freedom" (Pilkington, 2016: 212-213). Hence those who are trying to impose their particular brand 
of subjective truth in economics as the "robe objective science" (Pilkington, 2016: 213), are merely zealots unlike "moral philosophers" which help us explore certain moral dilemmas.

Economists can sustain arguments about profits, because they can establish where these "profits come from" and how "they work through the system. But there is really nothing that we can say with regard to the justness or unjustness of profits that a non-economist can have just as valid an opinion on" (Pilkington, 2016: 213). Economists have no "more objective validity than a similar statement made by, for example, a trade unionist or an anarcho-capitalist" (Ibid.). Although in principle Pilkington's posture seems impregnable, it can be argued that specific and "relative profit shares" of a certain set of class agents, can be "reduced", which entails an "ethical or moral political judgment" and yet "objective" in the sense that it's simply a question of adding and/or subtracting taxes, or differentiating levels of subsidies for the productive sectors/agents involved.

The standpoint although defensible, reluctantly finds itself undoing his own evaluation: "economics" is a "non-conservative" discipline, implying that the "system can be changed":

\begin{abstract}
"It is based on conventions, opinions and evaluations of what is good and bad in a given society at a given moment in time. It is not immutable or 'natural' and, above all, catastrophe will not occur if it is tampered with (...) It gives us tools we need to make changes to the system to produce desired outcomes. It does not tell us that we should definitely make particular changes (...) mankind should have no more need for those silly pseudo-objective stories sought to buttress certain political tendencies while shutting down the debates surrounding them. Anyone who requires such stories to justify their political proclivities is likely not someone who has much to contribute to real, practical and moral political debate." (Pilkington, 2016: 213-14)
\end{abstract}

However, certain specific policies, for example distributional struggles require the use of clear and concise arguments, even if not explicit, these contain "subjective" or ethico-moral judgements: relative shares of profits and/or salary levels, between and among agents and potential consequences cannot be washed away through a purely "objective" formulae. The clear cut or un-stained distinction between the ethical and evaluative space and the objective formulae are problematical for the same reasons which Pilkington underlines in much of his book: "social relations" are organized by conventional standards imposed by power asymmetries, the struggle for their transformations require politics and thus ethical-moral viewpoints, and hence in the last instance it implies "upsetting" to say the least, certain "liberties" or "individual freedoms", in other words, reconstructing politically the "individual-collective" divide. It's true no discourse or discipline can offer a general objective conception of the "truth" which should be followed by all or else or pay the consequences here or in heaven, but "deconstruction", and thus disappearance of ultimate foundations, offered in Pilkington's book, implies or compels him, to take a decision on matters which 
he sometimes renegade's. On occasions, the sanctity of the idea of "individual freedom" on which he sustains certain arguments cannot be safeguarded without the liability of reverting to marginalism and its notions of the attributes of the agents in question.

On the other hand, the problem with the metaphor or analogy for an "objective" formulae, and "switching" concepts of the hard sciences as a support to construct the conceptual realm (social) of the social sciences, finds an uncanny disruptive irony as we travel along Pilkington's book, since among one of the main arguments stressed to sustain de flawed character of marginalism, Pilkington points that the "material we deal with, economics" (Pilkington, 2016: 283) is unlike those which the modern sciences, and therefore "replicability", "causality" and calculability of experiments are a nonstarter,

Pilkington appropriately underlines, that the "material" with which it deals, the phenomena, molecules, etcetera, cannot be generalized in the social realm. In other words, even if we concede, and accept the hegemonic consensus that in the "hard sciences" the notion of "emergent properties" is pertinent, its incorporation as an explanation into the social realm begs thousands of questions, not only pertaining to the anthropomorphism which it engenders, but also notions of causality and determinism implicit or explicitly in the "hard sciences". But what must be underlined is the effort and decision to engage theoretically in this problem among others, which has become a kind of folklore by the publication of recent texts (King (2012); Hoover (2012), Backhouse; Boianovsky, (2013); Chavance, (2008); Hodgson, (2004); Wade Hands, (2012); Simon (1962).

Although I am aware that the process described by Pilkington by which an individual football fan behavior creates a specific "collective" response, is assuming the analogous outcome posed by Keynes's example of the negative effects when a "community" behaves in terms of the individual action by clearing his debts, the argument of the inadequacy of the metaphor "emergent properties" becomes theoretically unmanageable given the heterogenous characteristics of the agents, on the one hand, and Pilkington's own appreciation that the "realm" of "social sciences" cannot be examined by the logic of the "hard sciences".

My genuine concern is not really this aspect of the debate, but rather that agents (individuals, humans, non-humans) have to be observed as "heterogeneous" entities, within an antagonistic power-institutional realm, which, again, cannot be posed as a consequence and product of a necessary "individual" decision-choice, as the "methodological individual" posture portrays it. In contrast, a contingent instituted power process, whose "origin" need not be known in advance, does not require the banishing of "individuals" decision-choices, and/or insisting that the "social comes first".

The undetermined and contingent nature of the "social" realm (individual, agents, institutions $)^{35}$ is the theoretical aspect which is in dispute, and which in certain sections of the book 
becomes central. On the other hand, the empowering relations which individual or agents can generate, producing the "order" and "rules", whose origin in some quarters is argued as "spontaneous" (for example the "Austrian's; Hodgson, (1994; 2007) as an "emergent property", tends to challenge the most important of aspect of the argument: the antagonistic and contingent character of the social relations which would in turn demolish the assumed association and ties between the "elements" and "properties", on which the concept of "emergent properties" is built and on which "hard sciences" thrive.

As a concluding note Pilkington's book should be seen as an opportune publication, brave and daring given the academic and political context, I tried to develop only specific theoretical aspects with respect of the historical nature of agents, and the "economies", as well as the power asymmetries, a discourse which unwittingly was developed by Latin American structuralism during the 1950's. Explicitly I have radicalized certain themes which I believe follow from Pilkington's own argument and problematize certain apparently ambiguous theoretical and ethical standpoints; a new text would be needed to discuss his idea of the "subject" in Sartre, or his appreciation, of the discourse-reality distinction in his "schematism" model; hopefully, his Shackle-Keynesian renovation, to think the investment process, was not lost by the "peripheral" reading and the critique carried out in this article.

From my personal prejudices, decisive, par excellence, theme of the book was the examination of the "economic" realm and its agents, as a set of asymmetric power relations. Which cleared the ground to underline the ethical-political obligation to undertake critique of the actual situation of the discipline, which in turn given the contingent characteristic as to the manner income is generated and distributed, economics cannot turn into the theoretical fountain to "justify" the latter. Given that the origin of profits is, to say the least, distinct to the fable portrayed by "mainstream economics", and as Prebisch contends "its quantity and its variations are determined by the increment of money and production" and "its impossible to know to what extent profit is justified or not, because we lack, from the economic point of view elements of judgement" (Prebisch: 1948b: 359).

But if we accept the existence of a "compulsory mechanism" (Marxists perhaps use "exploitation mechanism") through which businessmen, after some interlude or cycle retrieve a supplement over their original inputs, it becomes a political issue as to what extent this enhanced amount of purchasing power is "justified". "Economics" cannot decide this aspect if its accepted that the notion of "efficiency" can only be made sense in terms of "profit". If during the upswing businessmen seem to "reap where they did not sow" (independently whether they incorporated new technology or not), the brunt of the decline of prices during the downswing is on their shoulders.

\footnotetext{
${ }^{35}$ See for example De Vroey notion of "trade technology" to think the problem of the organization of the "market", which is not solely related to "labor"; De Vroey, (2004a; 2004b)
} 
The ethical-political dilemma implicit in the schematic representation of the antagonistic contested space is clearer if we, for example, incorporate the idea that the agents in question are not "human individuals" but rather, cooperatives or other forms of collective forms, which possess in separation certain of their reciprocal conditions of their existence, then equally the issue of distribution and price bounds and the residual or "profit" does not evaporate; hence we cannot evade the individual-collective divide (Mirowski, 2019), we cannot negate the "other": a decision is call forth, a political engagement to discuss our forms of economic organization. 


\section{Bibliografía y fuentes documentales}

Ackerman Frank, Nadal Alejandro, Benetti Carlo, Gallagher Kevin P., Salas Carlo, (2004). Flawed Foundations of. General Equilibrium. Critical Essays on Economic Theory (Routledge Frontiers of Political Economy). London.

Backhouse R., Boianovsky, B., (2013). Transforming Modern Macroeconomics: Exploring Disequilibrium Microfoundations, 1956-2003 (Cambridge: Cambridge University Press).

Besomi, D., (2010). "Periodic crises": Clément Juglar between theories of crises and theories of business cycles. Research in the History of Economic Thought and Methodology, Volume 28-A, 169-283, by Emerald Group Publishing Limited.

Bruno De Conti, Daniela Magalhães Prates (2018). “The international monetary system hierarchy: current configuration and determinants, (Texto para Discussão. Unicamp. IE, Campinas, n. 335, abr. 2018).

Buñuel L., (1982). Mi ultimo suspiro, Plaza \& Janes, México.

Capraro Rodríguez, S., Perrotini Hernández, I. (2012). "Intervenciones cambiarias esterilizadas, teoría y evidencia: el caso de México" Contaduría y Administración, vol. 57, núm. 2, abril-junio, 2012, pp. $11-44$.

Chavance, B. (2008). Institutional Economics, London: Routledge.

Contaduría y Administración, vol. 57, núm. 2, abril-junio, 2012, pp. 11-44.

Connell, Raewyn (2007). Southern Theory: the Global Dynamics of Knowledge in Social Science, Cambridge: Polity.

Danby, C., (2017) The Known Economy: Romantics, Rationalists, and the Making of a World Scale, Abingdon, Oxon; Routledge.

Daniela Magalhães Prates \& Luiz Fernando De Paula, (2016). "Financial Flows To Emerging Economies And Policy Alternatives In Post-2008," [Proceedings of the 43rd Brazilian Economics Meeting] 117, ANPEC [Brazilian Association of Graduate Programs in Economics].

Daniela Magalhães Prates, (2017). "Monetary sovereignty, currency hierarchy and policy space: a postKeynesian approach”,, (Texto para Discussão. Unicamp. IE, Campinas, n. 315, set. 2017.)

De Vroey (2004b). "The History of Macroeconomics Viewed Against the Background of the MarshallWalras Divide. In De Vroey, Hoover K. D, editors (2004). The IS-LM Model. Its Rise, Fall and Strange Persistence.

De Vroey, Hoover K.D, editors (2004) The IS-LM Model: Its Rise, Fall, and Strange Persistence Durham, NC: Duke University Press.

De Vroey, M. (2004a). Involuntary Unemployment: The Elusive Quest for a Theory, London: Routledge.

Di Filippo A., (2013). Poder, capitalismo y democracia. Una visión sistémica desde América Latina, Santiago, Ril editores.

Duarte, P. G., Lima G. T, (editors) (2012). Microfoundations Reconsidered: The Relationship of Micro and Macroeconomics in Historical Perspective, (Cheltenham: Edward Elgar).

Düppe Till y Weintraub E. Roy, (2014). Finding Equilibrium: Arrow, Debreu, McKenzie and the Problem of Scientific Credit (Princeton: Princeton University Press.

Foucault, M., (1972). The Archeology of Knowledge, (1972). Tavistock Publications Limited, U.K.

Furtado C., (1954) A economia Brasileira, Rio de Janeiro: A Noite.

-, (1989) ABC da divida externa: o que fazer para tirar o país da crise financeira (Paz e Terra, Rio de Janeiro, 1989;

-, (1983,[1981]) El Brasil después del 'milagro’, (FCE, México, 1983, first edition in portuguese, 1981.

Helleiner Eric, (2014). Forgotten foundations of Bretton Woods: international development and the making of the postwar order (Ithaca and London: Cornell University Press).

Hodgson G. M., (1994) 'Hayek, evolution, and spontaneous order', in Mirowski, P. (Ed.): Natural Images in Economic Thought, Cambridge University Press, Cambridge, UK. 
---, (2001) How Economics Forgot History: The Problem of Historical Specificity in Social Science. London/ New York: Routledge.

---, (2004). The Evolution of Institutional Economics: Agency, Structure and Darwinism in American Institutionalism, London: Routledge.

---, (2006). "The ubiquity of habits and rules", Cambridge Journal of Economics, Volume 21, Issue 6, 1; November.

---, (2007). "Institutions and Individuals: Interaction and Evolution"

Organization Studies, Volume: 28 issue: 1: 95-116

---, (2011) "The eclipse of the uncertainty concept in mainstream economics". Journal of Economic Issues, 45(1):159-176.

Hoover K. D., (2012) “Microfoundational Programs" in Duarte, Lima 2012.

King Edward J., (2012). The Microfoundations Delusion: Metaphor and Dogma in the History of Macroeconomics (Cheltenham).

Kregel, Jan, (2018). "Preventing the last crisis: Minsky's forgotten lessons ten years after Lehman" in The state in the 21st century / editors, Ana Célia Castro, Fernando Filgueiras. - Brasília: Enap, 2018.

Krugman, P. R., (1997). Development, Geography, and Economic Theory; The MIT Press, 1997.

Lander Edgardo (coord.) (2000). La colonialidad del saber, Buenos Aires, Clacso/Unesco.

Luiz Fernando de Paula, Barbara Fritz \& Daniela M. Prates (2017) "Keynes at the periphery: Currency hierarchy and challenges for economic policy in emerging economies", Journal of Post Keynesian Economics, 40:2, 183-202.

López G. J., (2018). "Growth dilemmas in open middle-income economies: a reflection on Mexico's recent experience" Review of Keynesian Economics, Vol. 6 No. 3, Autumn 2018, pp. 333-351.

López G. J.; Assous, M., (2010) Michal Kalecki, Palgrave Macmillan, Great Britain.

---, 2008, La economía de Michal Kalecki y el capitalismo actual. Ensayos de teoría económica y economía aplicada, México, FCE, UNAM.

---, 2018, "Growth dilemmas in open middle-income economies: a reflection on Mexico's recent experience "Review of Keynesian Economics, Vol. 6 No. 3, Autumn, pp. 333-351.

Louçã Francisco, (2001) “Intriguing Pendula: Founding Metaphors In The Analysis Of Economic Fluctuations; January, Cambridge Journal of Economics 25(1):25-55.

Lavoie, M., (2006). Introduction to Post-Keynesian Economics, Basingstoke : Palgrave Macmillan.

Mallorquin Carlos, (2005) "Raúl Prebisch y el deterioro de la tesis de los términos de intercambio", Revista Mexicana de Sociología, núm. 2, abril-junio, 2005.

---, (2015) “Lord Keynes después de su muerte, según Raúl Prebisch", Estudios Críticos del Desarrollo, Estudios del Desarrollo, Universidad Autónoma de Zacatecas, vol. vi, núm. 9, 2015.

---, (2011). "Theoretical Misrecognitions as the Source of Development Theory Déjà Vú", in Márquez, Humberto; Soto, Roberto y Záyago, Edgar (coords.). El desarrollo perdido. avatares del capitalismo neoliberal en tiempos de crisis, México: Miguel Angel Porrúa (2011) pp. 71-106.

Meireles Monika (2016). Soberanía monetaria, desarrollo y pensamiento económico latinoamericano: enseñanzas de la dolarización ecuatoriana; Instituto de Investigaciones Económicas, UNAM.

Minsky Hyman P. (1986) "Stabilizing an Unstable Economy: The Lessons for Industry, Finance and Government", Archive Levy Economics Institute of Bard College (513).

Mirowski, P. (Ed.) (1994). Natural Images in Economic Thought, Cambridge University Press, Cambridge, UK.

Mirowski, P., (2017). "Hell Is Truth Seen Too Late", boundary 2 (2019) 46 (1): 1-53; Duke University Press Downloaded $18^{\text {th }}$ January 2019.

Nadal A., (2004). "Behind the building blocks: commodities and individuals in general equilibrium theory" In Ackerman, F., Nadal, A., Gallagher, K. (editors) (2004). The Flawed Foundations of General Equilibrium. Critical Essays on Economic Theory, New York: Routledge. 
Nadal, (2004a) "Choice of technique revisited: A critical review of the theoretical underpinnings" in Ackerman Frank, Nadal Alejandro, Benetti Carlo, Gallagher Kevin P., Salas Carlo, (2004).

Perrotini Hernández, I., (2002). "La economía de la información asimétrica", Revista Aportes, Facultad de Economía de la BUAP, Año VII núm. 19, enero-abril 2002, pp. 59-67.

-, Vázquez-Muñoz J. A., (2018) “El supermultiplicador, la acumulación de capital, las exportaciones y el crecimiento económico", El Trimestre Económico, vol. LXXXV (2). núm. 338, abril-junio de 2018, pp. 411-432.

Pilkington P., (2016). The Reformation in Economics: A Deconstruction and Reconstruction of Economic Theory, Palgrave Macmillan.

Reganti, A., (2016) “The Reserve: The Dollar, the Renminbi, and Status of Reserve," September 13, 2016. This GMO white paper is available with registration at www.gmo.com.

Prebisch Raul, (1944) "Teoría del interés a largo plazo" in Raúl Prebisch. Obras 1919-1948, vol. III, Fundación Raúl Prebisch; Buenos Aires, 1993.

-(1948). Apuntes de Economía Política (Dinámica Económica). in Prebisch, (1993). Raúl Prebisch. Obras 1919-1948, vol. IV, Fundación Raúl Prebisch; Buenos Aires, 1993.

---, (1948a). "Papel del beneficio en la realidad capitalista", en Prebisch, (1993).

-, (1948b). "Cotejo entre el esquema clásico y la realidad cíclica" en Apuntes de Economía Política (Dinámica Económica). en Prebisch, (1993)

---, (1949a). Teoría Dinámica de la Economía. Conferencias sustentadas por el Sr. Raúl Prebisch en la Escuela Nacional de Economía (febrero- marzo de 1949). Banco de México, México, in Prebisch, (1993).

---, (1949b). El desarrollo económico de la América Latina y sus principales problemas, en Prebisch, (1993). The United Nations document code is E/CN.12/89 (May).

---, (1949c). "Crecimiento, desequilibrio y disparidades: interpretación del proceso de desarrollo económico",in: Estudio económico de América Latina, 1949 - E/CN.12/164/Rev.1 - 1950

--, (1951) Problemas teóricos y prácticos del crecimiento económico, CEPAL, México, 28 may E/CN.12/221.

---, (1951a). "Problemas del desarrollo económico en América Latina", Third Conference, 24 of october 1951.

---, (1951b). "Problemas del desarrollo económico en América Latina", Third Conference, 25 of october 1951.

Robinson, J., (1980). “Time in Economic Theory”, Kyklos 33(2). pp. 219-29.

Rogerio P. Andrade \& Daniela Magalhães Prates (2013). "Exchange rate dynamics in a peripheral monetary economy", Journal of Post Keynesian Economics, 35:3, 399-416.

Russett, E. C., (1968). The concept of equilibrium in American social thought. Yale University Press, New Haven \& London.

Simon H. A., (1962). "The Arquitecture of Complexity", Proceedings of the American Philosophical Society, Vol. 106, no. 6, December, 1962

Sunkel O.; Paz P., (1970). Subdesarrollo latinoamericano y la teoría del desarrollo, México, Siglo XXI.

Triffin R., (1960) Gold and the Dollar Crisis, New Haven, Conn.: Yale University Press.

Ugarteche, O., (2104). Historia crítica del Fondo Monetario Internacional, (México, Instituto de Investigaciones Económicas-UNAM.

Wade Hands D., (2012) in (2012). "The rise and fall of Walrasian microeconomics: the Keynesian effect" in Duarte, Lima (2012) (editors) (2012). Microfoundations Reconsidered: The Relationship of Micro and Macroeconomics in Historical Perspective.

Wade Hands, D., (2005). "You want the social? You can't handle the social! Mirowski on the secret history", in Studies in History and Philosophy of Science; 36 (2005). 
Números anteriores:

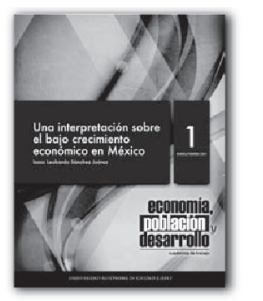

Economía, población y desarrollo.
Cuadernos de trabajo №1

Enero-Febrero 2011
Una interpretación sobre el bajo

crecimiento economico en México
Isaac Leobardo Sánchez Juárez

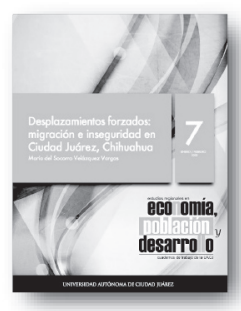

Economia, población y desarroll

Cuadernos de trabajo $\mathrm{N}$ -
Encro-Fcbrcro 2012

Desplazamientos forzados
migración e inseguridad

Ciudad Juárez, Chihuahua
Maria del Socorro Velázquez Varga

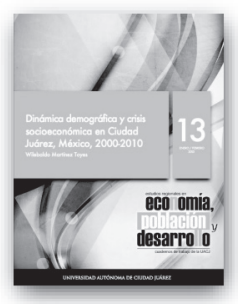

Economiá, población y desarrollo

de trabajo $N$

Dinámica demográ́fica y crisis
socieconómica en Ciudad Juáre Mexico, 2000-2010

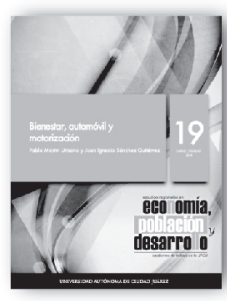

Economía, población y desarroll Enero - Febrero 2014 Bienestar, automóvil y motorización
Pablo Martín Urbano y Miosánchez Gutiérrez

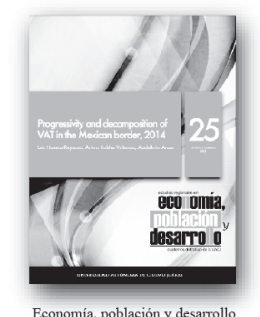

Cuadernos de trabajo No $_{0}$
Conomia,

Encro - Febrero 2015

Progressivity and decomposition of
VAT in the Mexican border, 2014 Abdelkim Araar

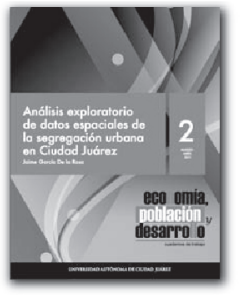

Economía, población y desarrollo.
Cuadernos de trabajo № 2

Marzo-Abril 2011

espaciales de la segregacón

Jaime Garcia De la Rosa

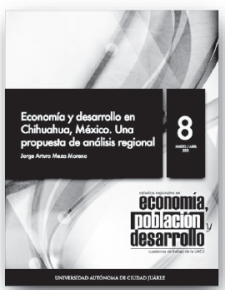

Economia, población y desarrollo

Cuadernos de trabajo №7

Economía y desarrollo en

propuesta de análisis regiona

Jorge Arturo Meza Moreno

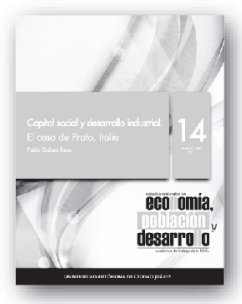

Economía, población y desarrollo

Marzo - Abri1 2013

Capital social y desarrollo

Pablo Galaso Reca

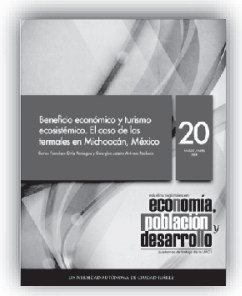

Economia, población y desarrollo

Marzo - Abril 2014

Beneficio económico y turismo

enico. El caso de las ter
en Michoacán, Mésico

arlos Franciseo Ortiz Paniagu

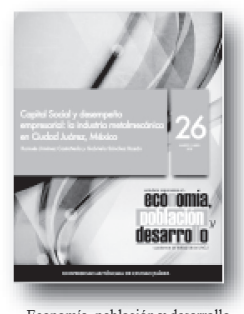

Economía, población y desarrollo

Cuadernos de trabajo № 26
Marzo - Abril 2015

Capital Social y desempeño empresa
la industria metalmecánica en

a industria metalmecánica en
Ciudad Juárez, México

Ramsés Jiménez Castañeda y
Gabriela Sáncez Bazán
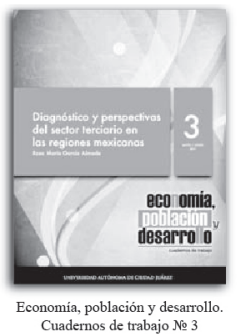

Diagnóstico y perspectivivas

regiones mexicanas
rosa Mária Garcia Almad

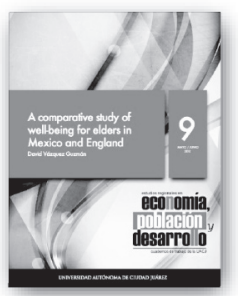

Economia, población y desarrollo

Cuadernos de trabajo № 9
Mayo - Junio 2012

A comparative study of

Mexico and England
David Vázquez Guzmán

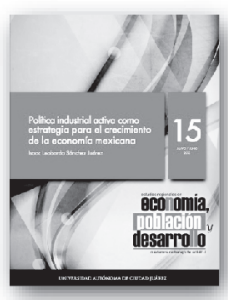

Economia, población y desarroll

Madernos de trabajo
Mayo - Junio 2013

Politica ind ustrial activa como

strategia para el crecimiento

Isaac Lcobardo Ś́nexicana
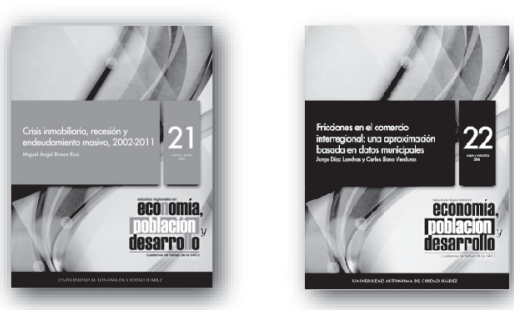

Economia, población y desarrollo

Cuademos de trabajo
Mayo - Junio 2014

Crisis inmobiliaria, recesión y
adeudamiento masivo, $2002-2011$

Miguel Ángel Rivera Rios

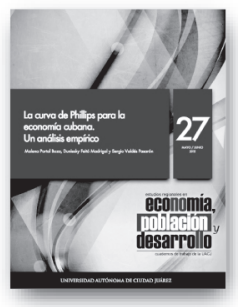

Economia, población y desarrollo

Cuadernos de trabajo № 27

a curva de Phillips para

economía cubana.

Malena Portal Boza, Duniesky Feitó

Economía, población y desarrollo.
Cuadernos de trabsio

julio-Agosto 201

Los indices IDH y FGT en la

mera década del siglo XX

Economía, población y decarrollo

Cuadernos de trabajo №
Julio - Agosto 2012

Political competition and the

edistribution in a federation

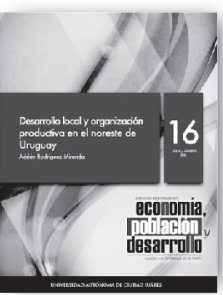

Economía, población y desarrollo

Cuadernos de trabajo №
Julio - Agosto 2013

Desarrollo local y organización
productiva en el noroeste de Urugu

Economía, población y desarrollo

Julio - Agosto 2014

Ficciones en el comercio

basada en datos municipales
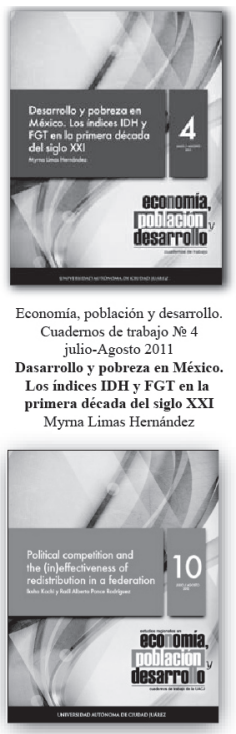

Jorge Diaz Lanchas y Carlos Llano Verduras
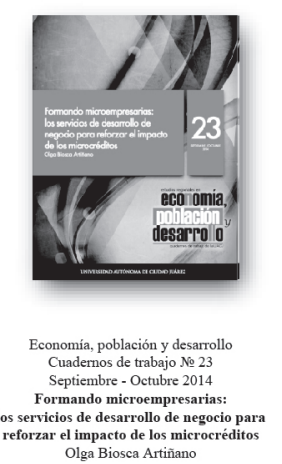

Cuadernos de trabajo № 24

El crecimiento de las regiones

el paradigma del desarrollo

divergente. Un marco térico
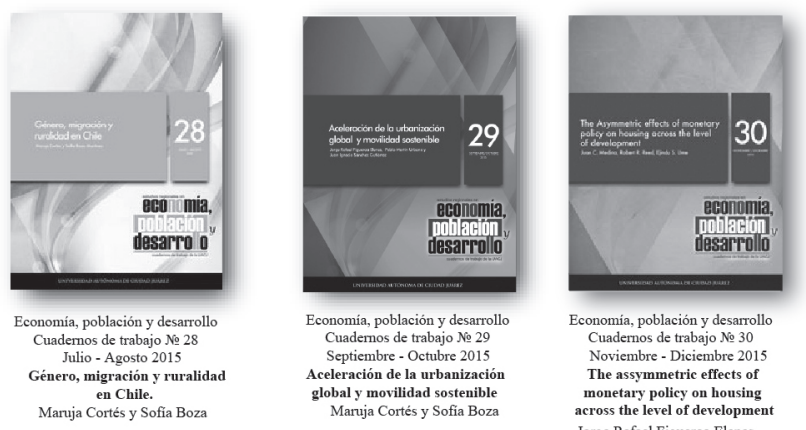

conomía, población y desarrol

Cuadernos de trabajo № 30

The assymmetric effects of

monetary policy on housing

Jorge Rafael Figueroa Elenes,

Juan Ignacio Sánchez Gutiérrez 
Números anteriores:
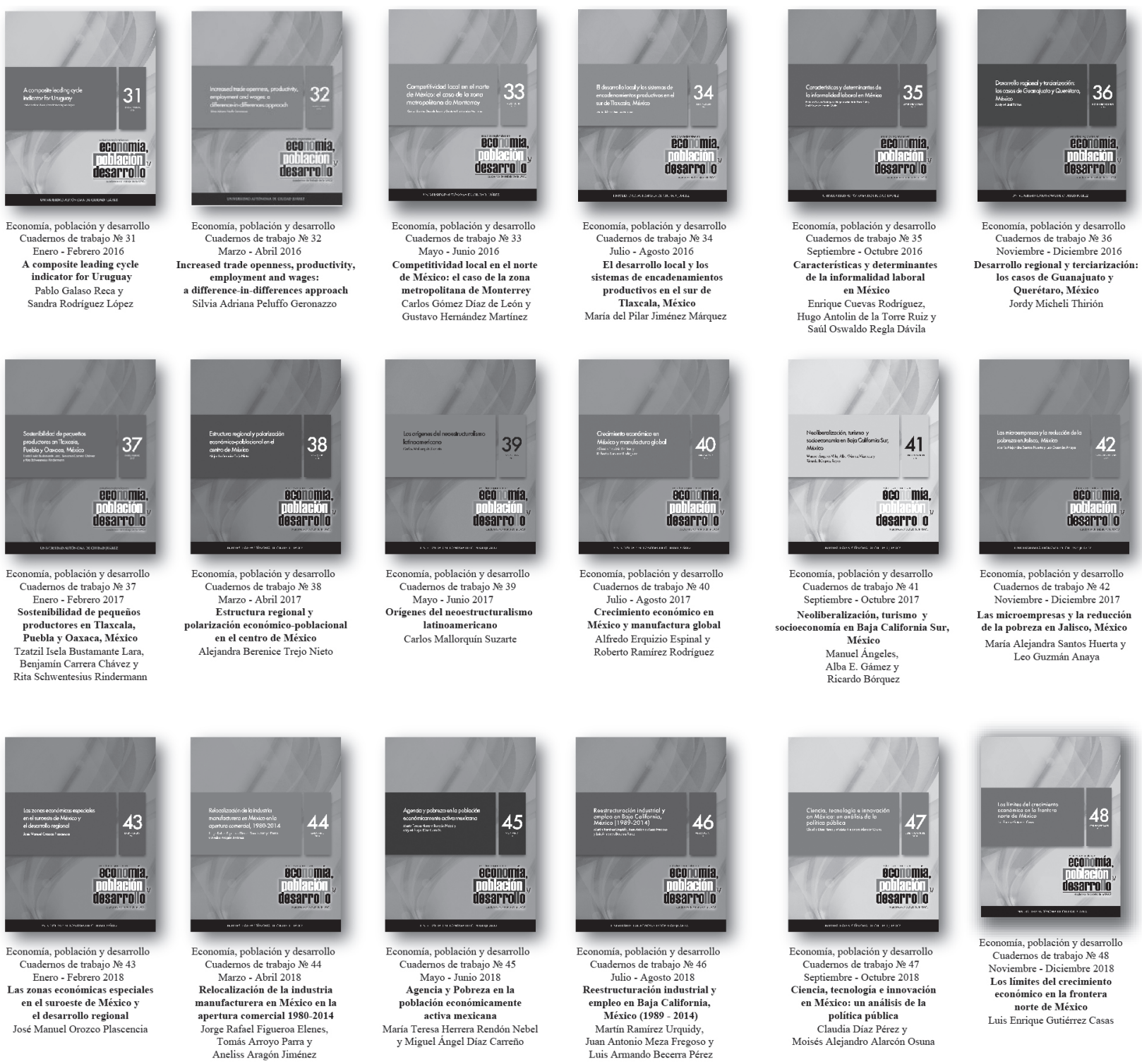

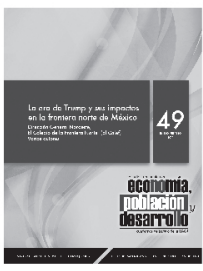

Economia, población y desarrollo Cuadernos de trabajo No 49
Enero - Febrero 2019

La era de Trump y sus impactos
en la frontera norte de Mésico Dirección General Noroeste Varios autores

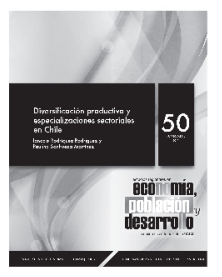

Economia, población y desarrollo Cuademos de trabajo № Marzo - Abril 2019

Diversiffeación productiva y
especializaciones sectoriales en Chile Ignacio Rodriguez Rodriguez
Paulina Sanhueza Martinez

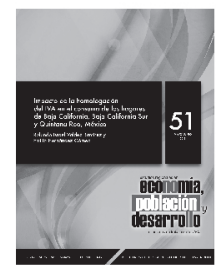

Economia, población y desarroll Cuademos de trabajo № 5
Mayo - Junio 2019

Mayo - Junio 2019 Impacto de la homologación del IVA
Imes Impacto de la homologación del IVA
en el consumo de los hogares de
Baja Calo Baja Califoria, Baja Califoria Sur
Quintana Roo, México Rolando Israel Valdez Ramirez y
Fmilio Hermández Gómez

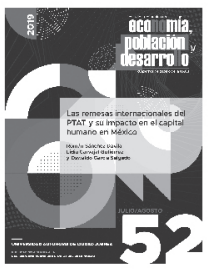

Economia, población y desarrollo
Cuadernos de trabajo № 52 Cuadernos de trabajo №
Julio - Agosto 2019

Las remesas internacionales el capital humano

Román Sánchez Dávila

Román Sánchez Davila
Lidia Carvajal Gutiérez Y
Oswaldo Garcia Salgado 


\section{$\rightarrow$ Normas Editoriales}

\section{Para el documento general:}

Tipo de letra: Times New Roman.

Tamaño: 11 puntos.

Interlineado: 1.5 espacios.

Títulos y subtítulos:

El texto principal en 11 puntos. Títulos 12 puntos (en resaltado). Subtítulos 11 puntos. Cada título y subtítulo deberá numerarse bajo el siguiente orden: $1,1.1,2,2.1,2.2 \ldots$

La extensión máxima de los cuadernos de trabajo será de 40 cuartillas.

La primera vez que se emplee una sigla en el texto se especificará primero su equivalencia completa y después la sigla.

\section{Hoja de presentación:}

Título:

14 puntos, centrado, resaltado.

Nombre de autor(es):

12 puntos

Resumen y abstract:

Debe incluir resumen en español y abstract (diez puntos), no mayor a 250 palabras

Palabras clave:

Incluir entre tres y cinco palabras clave, en español e inglés

Referencia del autor o autores:

Institución de adscripción, grado académico y líneas-grupos de investigación que desarrolla y a los que pertenece.

\section{Sistema de referencia de citas:}

Harvard-APA

Las citas bibliográficas en el texto deberán incluir entre paréntesis sólo el apellido del autor, la fecha de publicación y el número de página; por ejemplo: (Quilodrán, 2001: 33).

\section{Notación en sección de bibliografía y fuentes de información:}

Se deberá incluir al final del texto. Toda referencia deberá estar mencionada en el texto o notas de pie de página.

Cada referencia iniciará con el primer apellido o los apellidos, luego el nombre del autor, y después, entre paréntesis, el año de publicación seguido de un punto. Ejemplos:

Se deberá incluir al final del texto. Toda referencia deberá estar mencionada en el texto o notas de pie de página.

Cada referencia iniciará con el primer apellido o los apellidos, luego el nombre del autor, y después, entre paréntesis, el año de publicación seguido de un punto. Ejemplos:

Artículo:

Ros, Jaime (2008). "La desaceleración del crecimiento económico en México desde 1982”, en Trimestre Económico, vol. 75, núm. 299, pp. 537-560.

Libro:

Villarreal, René (2005). Industrialización, competitividad y desequilibrio externo en México. 
Un enfoque macroindustrial y financiero (1929-2010), México, Fondo de Cultura Económica. Capítulo de libro:

Castillo, Manuel Ángel (2003). "La política de inmigración en México: un breve recuento", en Manuel Ángel Castillo, Alfredo Lattes y Jorge Santibáñez (coords.), Migración y fronteras, Tijuana, El Colegio de la Frontera Norte / Asociación Latinoamericana de Sociología / El Colegio de México, pp. 425-451.

\section{Notas de pie de página:}

Se utilizarán para hacer indicaciones complementarias, aclaraciones o ampliación de una explicación. La notas de pie de página en Times New Roman, 10 puntos.

\section{Tipología de imágenes dentro del texto:}

Cuadro

Gráfica

Diagrama

Mapa

Figura

Todas las imágenes deben ser numeradas y mencionadas dentro del texto. A toda imagen debe incluirse la fuente.

Las indicaciones de la imagen: tipo y número de imagen, título de imagen y fuente se escriben en 10 puntos. En el texto poner como imagen los mapas, figuras, gráficas y diagramas -con el ánimo de no perder el formato realizado por el autor.

\section{Ecuaciones y fórmulas:}

Si se utilizan ecuaciones o fórmulas deberá utilizarse el editor de ecuaciones de Word y numerarse.

\section{Envío de trabajos}

Los trabajos deben ser enviados a la dirección de correo: lgtz@uacj.mx. Con el Dr. Luis Enrique Gutierrez Casas, editor de esta publicación.

La aceptación de cada colaboración dependerá de la evaluación de dos dictaminadores especialistas en la materia que se conservarán en el anonimato, al igual que el autor (autores) para efectos de la misma. 


\section{$\rightarrow$ Editorial Guidelines}

\section{For General Document:}

Font type: Times New Roman.

Size: font size 11 .

Paragraph: 1.5 line spacing.

Titles and subtitles: Main text font size 11. Titles font size 12 (Bold). Subtitles font size 11.

Each title and subtitle should be numbered in the following order: 1, 1.1, 2, 2.1, 2.2...

The maximum length of the workbooks will be 40 pages.

The first time an abbreviation is used in the text will be specified first complete equivalence and then stands.

\section{Front cover:}

Title:

Font size 14, centered, Bold.

Author name(s):

Font size 12.

Abstract:

It should include abstract in Spanish and abstract (font size 10), no more than 250 words.

Keywords:

Include three to five keywords, in Spanish and English.

Reference of author:

Institution of affiliation, academic degree and line-developed by research groups and belonging.

\section{Bibliographical appointment system:}

Harvard-APA

Citations in the text should include between parentheses only the author's name, publication date and page number, for example:

(Quilodrán, 2001: 33).

\section{Notation about Bibliography section and Information fonts:}

Should be included at the end of the text. All references must be mentioned in the text or footnotes page.

Each reference starts with the first name or last name, then the name of the author, and then, in parentheses, the year of publication followed by a period. Examples:

Article:

Ros, Jaime (2008). “La desaceleración del crecimiento económico en México desde 1982”, en Trimestre Económico, vol. 75, núm. 299, pp. 537-560.

Book:

Villarreal, René (2005). Industrialización, competitividad y desequilibrio externo en México. Un enfoque macroindustrial y financiero (1929-2010), México, Fondo de Cultura Económica.

Book chapter:

Castillo, Manuel Ángel (2003). "La política de inmigración en México: un breve recuento”, en Manuel Ángel Castillo, Alfredo Lattes y Jorge Santibáñez (coords.), Migración y fronteras, Tijuana, E1 Colegio de la Frontera Norte / Asociación Latinoamericana de Sociología / El Colegio de México, pp. 425-451. 


\section{Footnotes:}

Must be used to make additional indications, clarification or expansion of an explanation. The footnotes must be in Times New Roman, font size 10.

\section{Image typology inside text:}

Picture

Graph

Diagram

Map

Figure

All images must be numbered and mentioned in the text, should include the source image. The indications of the image: type and number of image, image title and source are written in 10 font size. In the text set as image maps, figures, graphs and charts-with the intention of not losing the formatting by the author.

\section{Equations and Formulae:}

When using equations or formulas should be used in Microsoft Word equation editor and numbered.

\section{Paper sending}

Entries must be sent to the email address: lgtz@uacj.mx. With Dr. Luis Enrique Gutiérrez Casas, editor of this publication.

Acceptance of each collaboration will depend on the evaluation of two examiners skilled in the art to be kept anonymous, like the author(s) for the same purposes. 
Publicacion afiliada a la

UNIVERSIDAD

AUTÓNOMA DE

CIUDAD JUÁREZ

$\begin{aligned} \text { O: } & \begin{array}{l}\text { Red } \\ \text { Iberoamericana } \\ \text { de Estudios } \\ \text { del Desarrollo }\end{array} \\ \text { RIED } & \end{aligned}$

Esta obra se editó y terminó de imprimir en

Ciudad Juárez, Chihuahua, México 


\section{estudios regionales en \\ cuadernos de trabajo de la UACJ}
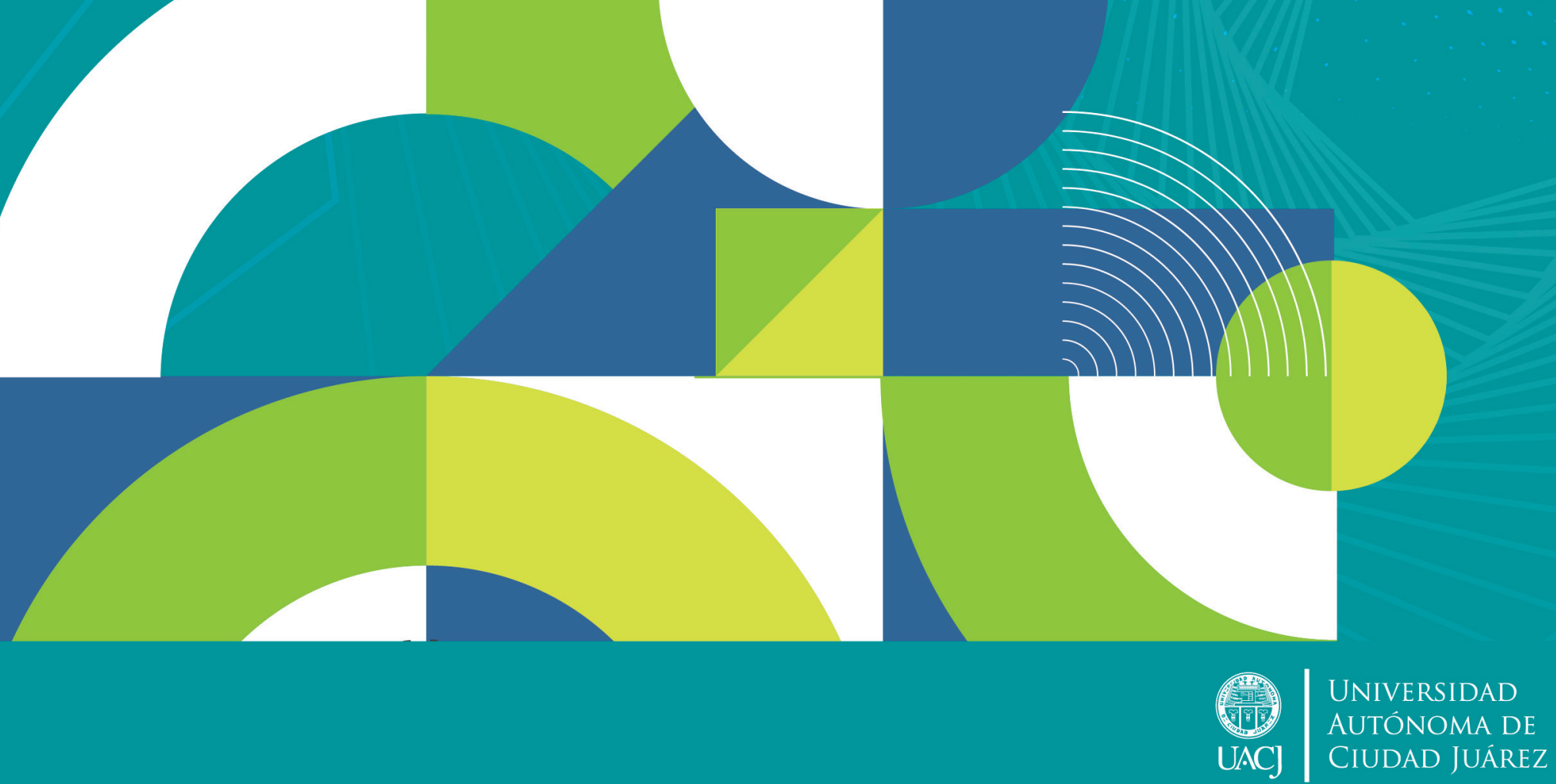

Cuadernos de Trabajo de la Universidad Autónoma de Ciudad Juárez, número 53, septiembre - octubre de 2019

Director y editor

Dr. Luis Enrique Gutiérrez Casas

\section{Comité editorial}

sección internaciona

Dra. Sofía Boza Martínez (Universidad de Chile, Chile)

Dra. Olga Biosca Artiñano (Glasgow Caledonian University, Reino Unido) Dra. Ángeles Sánchez Díez (Universidad Autónoma de Madrid, España) Dr. Thomas Fullerton Mankin (University of Texas at El Paso, Estados Unidos)

Dr. Adrián Rodríguez Miranda (Universidad de la República, Uruguay) Dra. Ikuho Kochi (Kanazawa University, Japón)

\section{Sección local}

(Universidad Autónoma de Ciudad Juárez)

Dra. Myrna Limas Hernández

Dra. Rosa María García Almada

Dr. Raúl Alberto Ponce Rodríguez

Dr. Isaac Leobardo Sánchez Juárez

Dr. Héctor Alonso Barajas Bustillos

Dr. Juan Carlos Medina Guirado
Universidad Autónoma de Ciudad Juárez Cuadernos de Estudios Regionales en Economía, Población y Desarrollo ISSN 2007-3739 Cuerpo Académico de Estudios Regionales en Economía, Población y Desarrollo

Edición impresa:

ISSN 2007-3739

Edición digital:

No. de reserva 04-2019-050218151500

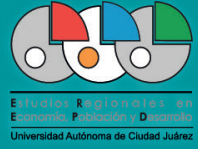

www.estudiosregionales.mx
UAC] $\mid$ CUERPOS ACADÉMICOS

Red

lberoamericana de Estudios del Desarrollo
Publicación afiliada a la Red Iberoamericana de Estudios del Desarrollo

๑ Universidad Autónoma de Ciudad Juárez Avenida Plutarco Elías Calles \#1210, Fovissste Chamizal Ciudad Juárez, Chih., México. www.uacj.mx 